Prepared in cooperation with the Metropolitan St. Louis Sewer District

\title{
Estimation of the Magnitude and Frequency of Floods in Urban Basins in Missouri
}

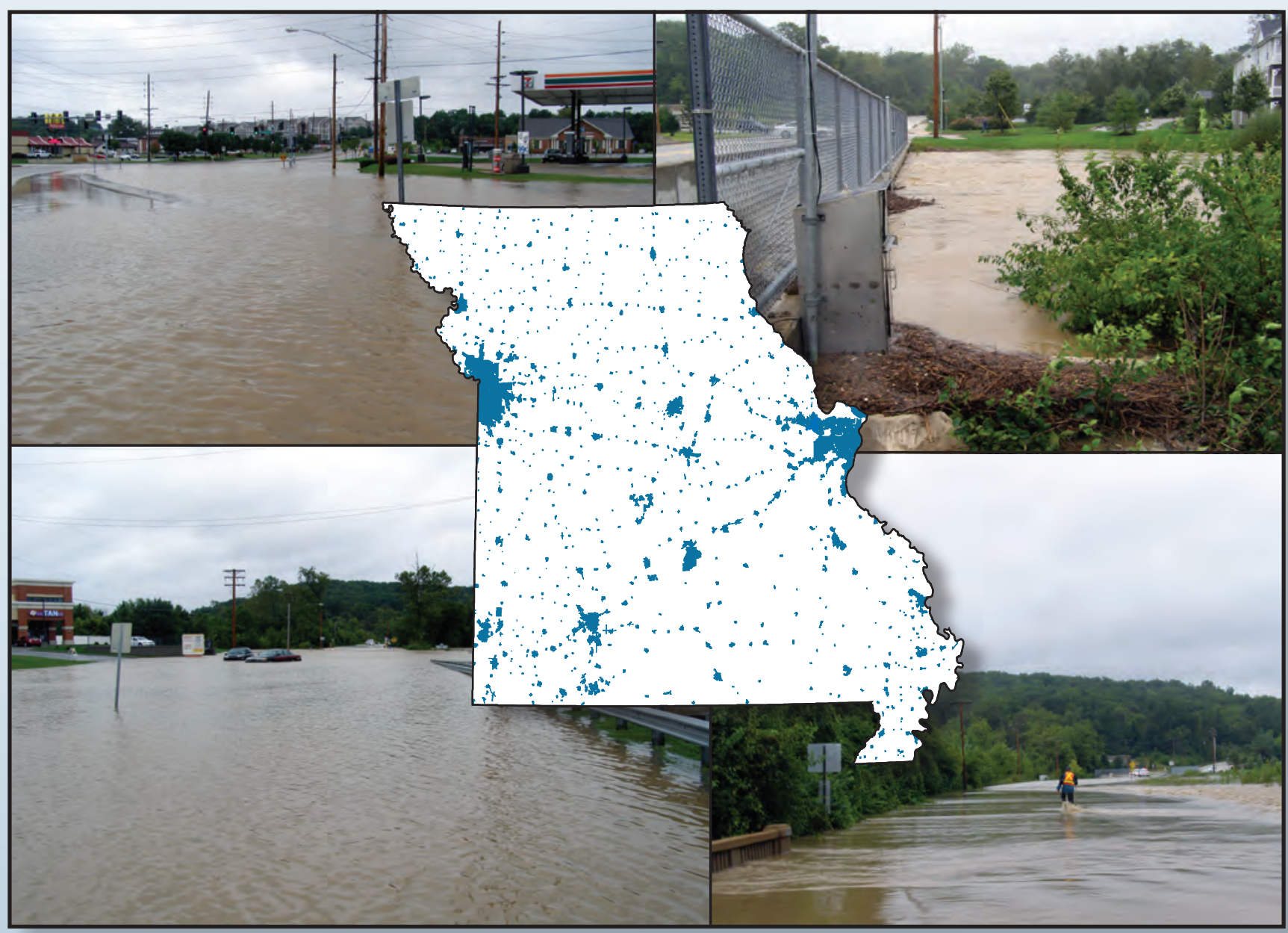

Scientific Investigations Report 2010-5073 
Cover photographs.

Grand Glaize Creek road overflow at intersection of Dougherty Road and Big Bend Road, near Valley Park, Missouri, September 14, 2008.

Grand Glaize Creek overflow along Dougherty Ferry Road, near Valley Park, Missouri, September 14, 2008.
Grand Glaize Creek along downstream side of Big Bend Road bridge, near Valley Park, Missouri, September 14, 2008.

Grand Glaize Creek right overbank flow on Big Bend Road, near Valley Park, Missouri, September 14, 2008. 


\section{Estimation of the Magnitude and Frequency of Floods in Urban Areas in Missouri}

By Rodney E. Southard

Prepared in cooperation with Metropolitan St. Louis Sewer District

Scientific Investigations Report 2010-5073 


\title{
U.S. Department of the Interior \\ KEN SALAZAR, Secretary \\ U.S. Geological Survey \\ Marcia K. McNutt, Director
}

\section{U.S. Geological Survey, Reston, Virginia: 2010}

\author{
For more information on the USGS — the Federal source for science about the Earth, its natural and living resources, \\ natural hazards, and the environment, visit http://www.usgs.gov or call 1-888-ASK-USGS \\ For an overview of USGS information products, including maps, imagery, and publications, \\ visit http://www.usgs.gov/pubprod \\ To order this and other USGS information products, visit http://store.usgs.gov
}

Any use of trade, product, or firm names is for descriptive purposes only and does not imply endorsement by the U.S. Government.

Although this report is in the public domain, permission must be secured from the individual copyright owners to reproduce any copyrighted materials contained within this report.

Suggested citation:

Southard, R.E., 2010, Estimating the magnitude and frequency of floods in urban basins in Missouri: U.S. Geological Survey Scientific Investigations Report 2010-5073, 27 p. 


\section{Contents}

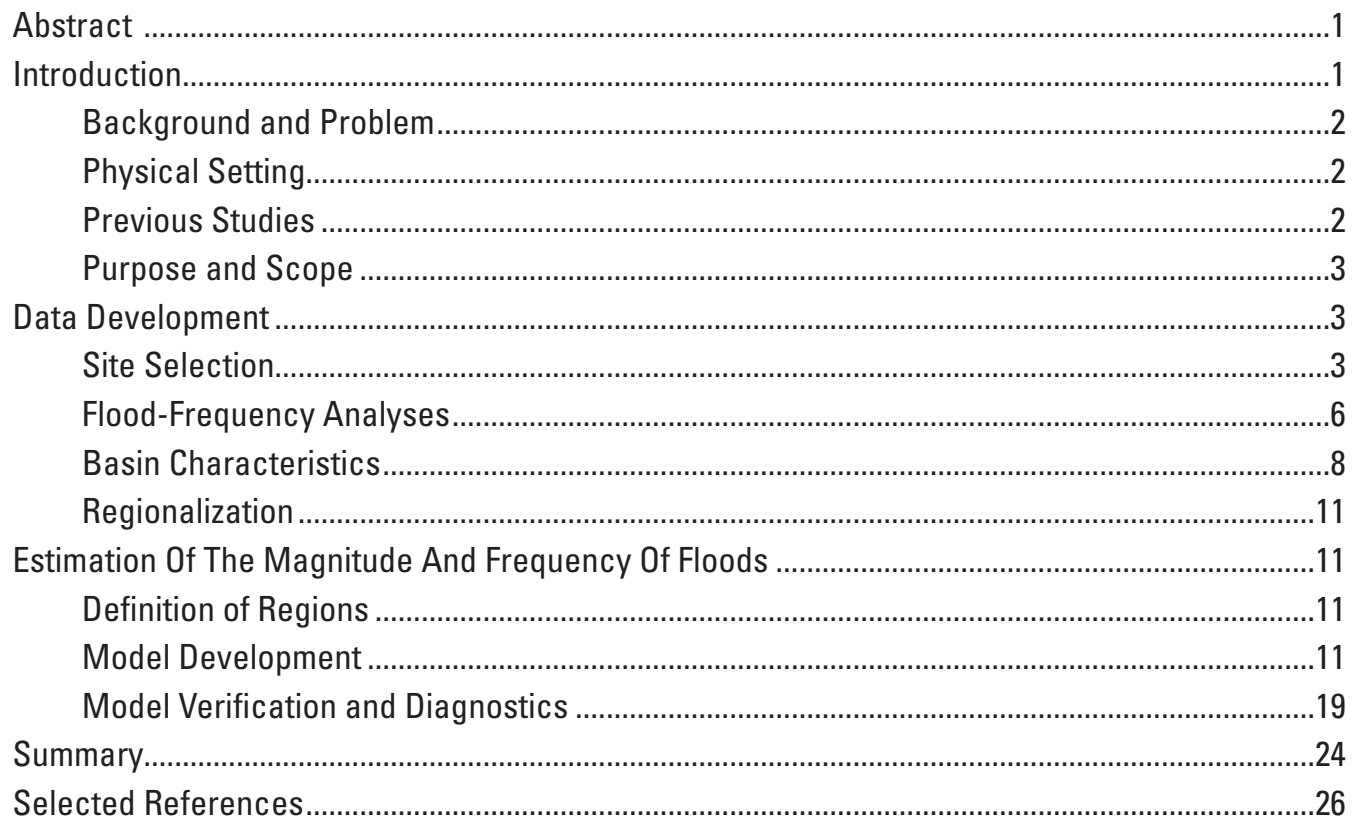

\section{Figures}

1-2. Maps showing:

1. Location of urban areas in and adjacent to Missouri and selected urban areas with U.S. Geological Survey streamgages used in this study

2. Location of streamgages in and adjacent to Missouri used in this study

3-6. Graphs showing:

3. Residuals of the regression equations for estimating the magnitude of the $(A) 50-,(B) 10-$, and $(C)$ 1-percent annual exceedance probability flood in relation to drainage area and percent impervious area

4. Comparison of observed and estimated peak flows of the (A) 50-, (B) 10-, and (C) 1-percent annual exceedance probability flood.

5. Drainage area and impervious area basin characteristics at U.S. Geological Survey streamgages in urban areas in and adjacent to Missouri.

6. Maximum recorded flood discharges at U.S. Geological Survey streamgages in urban areas in and adjacent to Missouri in relation to estimated peak flows from the regression equations for the 1- and 0.2-percent annual exceedance probability flood using 46 percent impervious area 


\section{Tables}

1. Description of selected streamgages in urban areas in and adjacent to Missouri

2. Basin characteristics of streamgages in urban areas in and adjacent to Missouri used in the development of urban regression equations

3. Flood-frequency statistics for annual peak flow data from 35 U.S. Geological Survey streamgages in urban areas in and adjacent to Missouri

4. Flood discharges at given annual exceeedance probabilities for streamgages in urban areas in and adjacent to Missouri

5. Weighted least-squares regression equations for streams in urban areas in Missouri

6. Variance of estimated values for U.S. Geological Survey streamgages in urban areas in and adjacent to Missouri

7. Accuracy statistics of weighted least-squares regression equations for urban basins in Missouri

8. Model error variances, Student's t distribution, and covariance matrices of regression equations for urban basins in Missouri.

9. Ranges of basin characteristics used to develop the regression equations for urban basins in Missouri

10. Results of sensitivity analyses presented as percent change in computed flood discharge as a result of a 10 - and 20 -percent change of the input basin characteristic

11. Flood discharges at the 1-percent annual exceedence probabilities for rural and urban regression equations at selected U.S. Geological Survey streamgages. 


\section{Conversion Factors and Datums}

\begin{tabular}{lcl}
\hline Multiply & By & To obtain \\
\hline inch (in.) & Length & \\
foot $(\mathrm{ft})$ & 2.54 & centimeter $(\mathrm{cm})$ \\
foot per mile $(\mathrm{ft} / \mathrm{mi})$ & 0.3048 & meter $(\mathrm{m})$ \\
mile $(\mathrm{mi})$ & 0.1894 & meter per kilometer \\
\hline & 1.609 & kilometer $(\mathrm{km})$ \\
\hline square mile $\left(\mathrm{mi}^{2}\right)$ & Area & \\
square mile $\left(\mathrm{mi}^{2}\right)$ & 259.0 & hectare $(\mathrm{ha})$ \\
\hline & 2.590 & square $\mathrm{kilometer}\left(\mathrm{km}^{2}\right)$ \\
\hline cubic foot $\left(\mathrm{ft}^{3}\right)$ & Volume & \\
\hline & 0.02832 & cubic meter $\left(\mathrm{m}^{3}\right)$ \\
\hline foot per second $(\mathrm{ft} / \mathrm{s})$ & Flow Rate & \\
\hline cubic foot per second $\left(\mathrm{ft}^{3} / \mathrm{s}\right)$ & 0.3048 & meter per second $\left(\mathrm{m}^{2} / \mathrm{s}\right)$ \\
\hline
\end{tabular}

Horizontal coordinate information is referenced to North American Datum of 1983 (NAD 83).

Elevation, as used in the report, refers to the distance above the North American Vertical Datum of 1988 (NAVD88). 



\title{
Estimation of the Magnitude and Frequency of Floods in Urban Areas in Missouri
}

\author{
By Rodney E. Southard
}

\section{Abstract}

Streamgage flood-frequency analyses were done for 35 streamgages on urban streams in and adjacent to Missouri for estimation of the magnitude and frequency of floods in urban areas of Missouri. A log-Pearson Type-III distribution was fitted to the annual series of peak flow data retrieved from the U.S. Geological Survey National Water Information System. For this report, the flood frequency estimates are expressed in terms of percent annual exceedance probabilities of 50, 20, $10,4,2,1$, and 0.2 . Of the 35 streamgages, 30 are located in Missouri. The remaining five non-Missouri streamgages were added to the dataset to improve the range and applicability of the regression analyses from the streamgage frequency analyses.

Ordinary least-squares was used to determine the best set of independent variables for the regression equations. Basin characteristics selected for independent variables into the ordinary least-squares regression analyses were based on theoretical relation to flood flows, literature review of possible basin characteristics, and the ability to measure the basin characteristics using digital datasets and geographic information system technology. Results of the ordinary least-squares were evaluated on the basis of Mallow's $C p$ statistic, the adjusted coefficient of determination, and the statistical significance of the independent variables. The independent variables of drainage area and percent impervious area were determined to be statistically significant and readily determined from existing digital datasets. The drainage area variable was computed using the best elevation data available, either from a statewide 10 -meter grid or high-resolution elevation data from urban areas. The impervious area variable was computed from the National Land Cover Dataset 2001 impervious area dataset. The National Land Cover Dataset 2001 impervious area data for each basin was compared to historical imagery and 7.5-minute topographic maps to verify the national dataset represented the urbanization of the basin at the time streamgage data were collected. Eight streamgages had less urbanization during the period of time streamflow data were collected than was shown on the 2001 dataset. The impervious area values for these eight urban basins were adjusted downward as much as 23 percent to account for the additional urbanization since the streamflow data were collected.

Weighted least-squares regression techniques were used to determine the final regression equations for the statewide urban flood-frequency equations. Weighted least-squares techniques improve regression equations by adjusting for different and varying lengths in streamflow records. The final flood-frequency equations for the 50-, 20-, 10-, 4-, 2-, 1-, and 0.2 -percent annual exceedance probability floods for Missouri provide a technique for estimating peak flows on urban streams at gaged and ungaged sites. The applicability of the equations is limited by the range in basin characteristics used to develop the regression equations. The range in drainage area is 0.28 to 189 square miles; range in impervious area is 2.3 to 46.0 percent.

Seven of the 35 selected streamgages were used to compare the results of the existing rural and urban equations to the urban equations presented in this report for the 1-percent annual exceedance probability. Results of the comparison indicate that the estimated peak flows for the urban equation in this report ranged from 3 to 52 percent higher than the results from the rural equations. Comparing the estimated urban peak flows from this report to the existing urban equation developed in 1986 indicated the range was 255 percent lower to 10 percent higher. The overall comparison between the current (2010) and 1986 urban equations indicates a reduction in estimated peak flow values for the 1-percent annual exceedance probability flood.

\section{Introduction}

Hydraulic design of bridges and culverts, the establishment of flood-insurance rates, and the designation of emergency routes require information about the flood characteristics of streams. These characteristics depend substantially on upstream basin characteristics. Urban basins are characterized by substantial development consisting of streets, highways, residential homes, and commercial buildings. This development results in impervious surfaces that limit infiltration of precipitation, reduce runoff times, and increase peak flows in channels. Rural basins are characterized by agricultural land 
use, forests, and natural channels. Regulated streams in rural or urban basins are characterized by upstream locks and dams, and these streams have unique flow characteristics dependent on the operational plans of these structures. Peak flows on regulated streams typically are delayed and attenuated compared to unregulated streams.

Estimates of the peak flow flood characteristic for urban basins are determined separately from rural basins. The increase in impervious area of urban basins and efficient drainage systems results in higher peak flows and decreased basin response times compared to rural basins. Peak flow estimates are computed using regression equations. The dependent variable is derived from frequency analyses of flow data from streamgages located in urban basins. The independent variables consist of basin characteristics that describe basin size and shape characteristics, land use, and climatic variables.

\section{Background and Problem}

Proper design of bridges and culverts, land-use planning, and flood-risk assessments are all dependent on the best available estimates of peak flood discharges to minimize costs and protect lives and property. There has been a need to re-evaluate the current (2010) statewide urban flood frequency equations in Missouri for several reasons. First, the last set of urban equations (Becker, 1986) was based on streamgages with data only through the 1984 water year (October 1 to September 30). Between 1985 and 2008, 24 years of additional streamflow data have been collected at selected streamgages. Also, 15 streamgages have been established or re-activated in the St. Louis area and are available for regression analyses. Second, computers and their associated storage and processing capabilities have increased dramatically since 1984. Large digital datasets now can be evaluated and processed to more accurately define historically recognized basin characteristics and evaluate potentially new characteristics that in the past were too computationally intensive to do by hand or with earlier computer systems. Third, the field of statistical analyses has progressed because of computer capabilities and improved methods such as accounting for length of record at streamgages and correlation of streamgages on the same stream and in similar geographic regions. A fourth reason is to define the 0.2-percent annual exceedance probability flood for urban basins for risk assessments. Previous studies estimated floods only up to the 100-year recurrence interval (1-percent annual exceedance probability flood); Becker (1986) and other authors of previous flood frequency studies in Missouri expressed flood-frequency estimates in terms of T-year discharges, where $\mathrm{T}$ is a recurrence interval that indicates the average number of years between occurrences of peak discharges of the same or greater magnitude. For these reasons, the U.S. Geological Survey (USGS) conducted a study, in cooperation with the Metropolitan St. Louis Sewer District, to develop and apply a new set of regression equations for estimating the magnitude and frequency of floods in urban basins in Missouri.

\section{Physical Setting}

The state of Missouri is located in the Midwest region of the continental United States with no topographic barriers to hinder cold air masses from the northern plains and Canada or warm air masses from the Gulf of Mexico. Copious amounts of precipitation sometimes are produced as thunderstorms develop and re-develop along fronts that separate contrasting air masses. For example, thunderstorms on August 12 and 13, 1982, in the Kansas City area resulted in a 24-hour rainfall report of 12.6 inches and widespread flash flooding (Becker and Alexander, 1983). Tropical systems from the Gulf of Mexico also provide substantial amounts of precipitation as they move across the state. Tropical systems typically do not have the rainfall intensity as frontal type thunderstorms, but they are capable of producing substantial amounts of rainfall over large areas. Mean annual rainfall rates vary from 34 inches in the northwest to 50 inches in the southeast part of the state (Missouri Climate Center, 2009).

Physical features within a state or region can affect the runoff characteristics of flood flows. Elevation varies from about 200 feet above the North American Vertical Datum of 1988 in the southeast part of Missouri to about 1,700 feet in south-central Missouri. Local relief varies from less than about 30 feet in the southeast part of the state to 500 feet or more in central and south-central Missouri. Stream slopes in the southeast part of the state are relatively low, with slopes averaging about 1.5 feet per mile. Flash flooding is a concern in other urban areas of the state where slopes of 150 feet per mile exist (Alexander and Wilson, 1995).

Drainage patterns are sometimes altered in urban areas. Stream channels often are straightened and enlarged, and may even be routed underground in long culverts or conduits. The hydraulic characteristics of streams in urban areas may be altered because of constrictions from the numerous road and highway crossings of stream channels. Retention ponds in urban areas also change the dependent times and magnitudes of peak discharges on urban streams (Feaster and Guimaraes, 2004).

\section{Previous Studies}

Spencer and Alexander (1978) documented an investigation to define flood frequency estimates for urban basins in Missouri. The study area was St. Louis County and a network of 30 streamgages was established to define the hydrologic characteristics in this region of the state. Data from the streamgages were used to develop regression equations and nomographs to estimate flood frequencies. Independent variables were drainage area and percentage of impervious area. Drainage area was computed manually using a mechanical planimeter and USGS 7.5-minute quadrangle topographic 
maps at a scale of 1:24,000. Macroscopes with scalar reticules were used to measure areas of impervious surface from aerial photography at a scale of 1:8,400. Standard errors of estimate ranged from 15.7 to 17.8 percent for the regression equations. The equations were applicable for streams in St. Louis County with a drainage area range of 0.8 to 39 square miles and an impervious area range of 1 to 32 percent.

Sauer and others (1983) completed a nationwide study of urban basins to estimate selected flood annual exceedance probabilities of 50 to 0.2 percent for ungaged sites. The study utilized data from 269 streamgages located in urban basins in 56 cities and 31 states. Their work resulted in two sets of seven-parameter equations and one set of threeparameter equations. The standard error of estimate for the seven-parameter equations ranged from 32 to 49 percent. The standard error of estimate for the three-parameter equations ranged from 40 to 52 percent. Common independent variables used in the three sets of equations were drainage area, basin development factor, and rural discharge. The basin development factor variable is an index of urbanization, which provides a measure of the efficiency of the drainage system. The efficiency of a drainage system is based on the percentage of channel improvements and linings, storm sewers, and curb-and-gutter streets. The rural discharge variable is based on frequency analyses of peak discharges in rural basins. This rural discharge variable is important for explaining geographical variations in runoff from urban areas in different parts of the country.

Becker (1986) is the most recent urban flood frequency study applicable for urban basins in Missouri and documented the first statewide urban flood frequency equations for Missouri. To develop the regression equations for Missouri 37 USGS streamgages were used; of these 27 were located in urban basins, and 10 were located in predominantly rural basins. The rural basins were included in the study to increase the number of streamgages for statistical analyses, and to extend the applicability of the equations developed by assuming a minimum of 1 percent of impervious area in the rural basins. Streamgage records were extended using a rainfall-runoff model and by simulating runoff using long term precipitation records. Becker (1986) provided flood-frequency estimates from 50 to 1 percent of the flood annual exceedance probability with two sets of equations. The first set of equations included the independent variables drainage area and the basin development factor from Sauer and others (1983). The second set of equations included drainage area and impervious area as independent variables. The range of standard errors of estimate from these sets of equations was 25.9 to 32.9 percent. These equations were applicable for drainage area from 0.28 to 38.9 square miles, a basin development factor from 0 to 11 , and percentage of impervious area from 1 to 34 .

\section{Purpose and Scope}

The purpose of this report is to document the development and application of regression equations for estimating the magnitude and frequency of floods in urban basins in Missouri. The flood frequency estimates for the flood annual exceedance probabilities of 50-, 20-, 10-, 4-, 2-, 1-, and 0.2-percent (recurrence intervals of 2-, 5-, 10-, $25-, 50-, 100-$, and 500-years) were selected for this study. The equations were based on data from 35 streamgages in urban basins in and adjacent to Missouri (fig. 1). Of the 35 USGS streamgages, 30 were spatially located in Missouri, 3 were located in Arkansas, 1 was located in Kansas, and 1 streamgage was located in Oklahoma. Streamgages outside of Missouri were selected to extend the range of data used for the independent variables. This report supersedes previous USGS urban flood frequency reports for Missouri.

This report describes the site selection, flood-frequency analyses, basin characteristics, and development and verification of the regression equations. In addition to observed data, previous studies in Missouri relied on calibration and simulation of flood peaks at selected streamgages. This study focused on using observed peak flows determined by direct or indirect measurements at all streamgages. The most recent statistical techniques in streamgage flood frequency (expected moments algorithm) and weighted least-squares regression analyses were used to develop the best possible regression equations. Independent variables were selected for data availability and computation in geographic information systems (GIS), as well as being statistically significant at the 0.05 probability level. Ordinary least-squares (OLS) regression was used to determine the best set of independent variables for estimation of flood peaks, and weighted least-squares (WLS) regression was used to compute the final regression coefficients.

\section{Data Development}

A reliable source of hydrologic information available for flood frequency estimation is the annual time series data collected at USGS streamgages. Data may be collected continuously by mechanical or digital recorders. Data also may be collected intermittently with devices that collect only the peak stage of an event. The highest recorded flood event each year reflects an annual time series at that specific streamgage.

\section{Site Selection}

The study area included urban areas in the State of Missouri. An emphasis of this study was to develop a set of regression equations based on observed peak flow values at selected urban streamgages. The initial review of urbanized basins resulted in a list of more than 70 streamgages with sufficient record length of 9 years or longer. Further evaluation of the initial list of streamgages and upstream basins resulted in a 


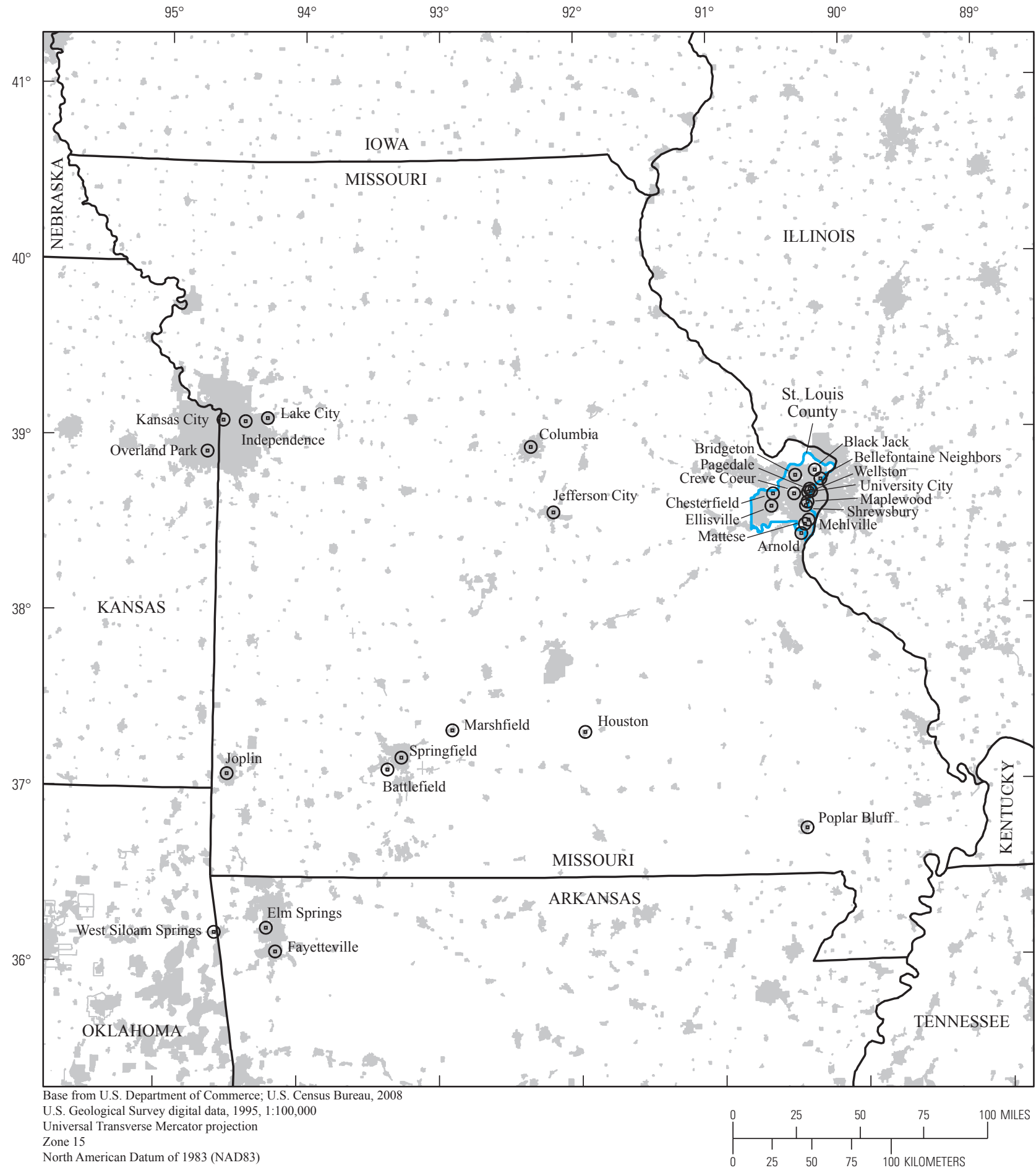

\section{EXPLANATION}

Urban area

(-) Location of urban areas with

U.S. Geological Survey streamgages

Figure 1. Location of urban areas in and adjacent to Missouri and selected urban areas with U.S. Geological Survey streamgages used in this study. 
Table 1. Description of selected streamgages in urban areas in and adjacent to Missouri.

[USGS, U.S. Geological Survey; ddmmss, degree, minute, second]

\begin{tabular}{|c|c|c|c|c|c|}
\hline $\begin{array}{c}\text { Site } \\
\text { number } \\
\text { (fig. 2) }\end{array}$ & Streamgage name & $\begin{array}{c}\text { USGS } \\
\text { streamgage } \\
\text { number }\end{array}$ & $\begin{array}{l}\text { Latitude } \\
\text { (ddmmss) }\end{array}$ & $\begin{array}{l}\text { Longitude } \\
\text { (ddmmss) }\end{array}$ & $\begin{array}{c}\text { Period } \\
\text { of record } \\
\text { (water year) }\end{array}$ \\
\hline 1 & Indian Creek at Overland Park, Kan. & 06893300 & 395626 & 944016 & 1964-2008 \\
\hline 2 & Blue River at Kansas City, Mo. & 06893500 & 395725 & 943332 & 1939-2008 \\
\hline 3 & Brush Creek at Kansas City, Mo. & 06893560 & 390222 & 943506 & 1971-1982, 1999 \\
\hline 4 & Brush Creek at Rockhill Road in Kansas City, Mo. & 06893562 & 390221 & 943443 & 1999-2008 \\
\hline 5 & Rock Creek at Independence, Mo. & 06893600 & 390436 & 942702 & $1967-1975$ \\
\hline 6 & Little Blue River near Lake City, Mo. & 06894000 & 390602 & 941801 & $1948-2008$ \\
\hline 7 & Cow Branch near Columbia, Mo. & 06910200 & 390010 & 921925 & 1955-1979 \\
\hline 8 & Hinkson Creek at Columbia, Mo. & 06910230 & 395539 & 922023 & $\begin{array}{l}\text { 1967-1981, } \\
1987-1991\end{array}$ \\
\hline 9 & Dickerson Creek Tributary near Jefferson City, Mo. & 06910430 & 393445 & 921643 & 1970-1979 \\
\hline 10 & Niangua Branch at Marshfield, Mo. & 06923000 & 392049 & 925445 & $1951-1979$ \\
\hline 11 & Coyle Branch at Houston, Mo. & 06929000 & 391925 & 915711 & $1950-1979$ \\
\hline 12 & Shotwell Creek at Highway 340 near Ellisville, Mo. & 06935800 & 393705 & 903459 & $1960-1979$ \\
\hline 13 & Creve Coeur Creek at Chesterfield, Mo. & 06935850 & 393847 & 903137 & $1998-2008$ \\
\hline 14 & Creve Coeur Creek near Creve Coeur, Mo. & 06935890 & 394057 & 902920 & $\begin{array}{l}1972-1979 \\
1997-2008\end{array}$ \\
\hline 15 & Fee Fee Creek near Bridgeton, Mo. & 06935955 & 394340 & 902650 & $\begin{array}{l}1972-1979 \\
1996-2008\end{array}$ \\
\hline 16 & Cowmire Creek at Bridgeton, Mo. & 06935980 & 394551 & 902558 & $\begin{array}{c}1972-1979 \\
1998-2008\end{array}$ \\
\hline 17 & Coldwater Creek near Black Jack, Mo. & 06936475 & 394904 & 901504 & $1997-2008$ \\
\hline 18 & Maline Creek at Bellefontaine Neighbors, Mo. & 07005000 & 394412 & 901334 & 1996-2008 \\
\hline 19 & River Des Peres near University City, Mo. & 07010022 & 394005 & 901925 & $1997-2008$ \\
\hline 20 & River Des Peres Trib. at Pagedale, Mo. & 07010030 & 394036 & 901853 & 1997-2008 \\
\hline 21 & Engelholm Creek near Wellston, Mo. & 07010035 & 394057 & 901810 & 1998-2008 \\
\hline 22 & Deer Creek at Maplewood, Mo. & 07010086 & 393603 & 901934 & $1996-2008$ \\
\hline 23 & MacKenzie Creek near Shrewsbury, Mo. & 07010090 & 393436 & 901924 & $1997-2008$ \\
\hline 24 & Gravois Creek near Mehlville, Mo. & 07010180 & 393136 & 901758 & $1997-2008$ \\
\hline 25 & Martigney Creek near Arnold, Mo. & 07010208 & 392927 & 901734 & $1998-2008$ \\
\hline 26 & Mattese Creek near Mattese, Mo. & 07019317 & 392859 & 902027 & 1996-2008 \\
\hline 27 & Town Branch at B.R. 62 at Fayetteville, Ark. & 07048480 & 390325 & 941031 & $1997-2008$ \\
\hline 28 & Town Branch Tributary at Highway 16 at Fayetteville, Ark. & 07048490 & 390253 & 940943 & 1997-2008 \\
\hline 29 & Wilson Creek at Springfield, Mo. & 07052000 & 391113 & 931952 & 1999-2008 \\
\hline 30 & Wilson Creek near Springfield, Mo. & 07052100 & 391006 & 932213 & $\begin{array}{c}1972-1980 \\
1999-2008\end{array}$ \\
\hline 31 & Wilson Creek near Battlefield, Mo. & 07052160 & 390703 & 932413 & $\begin{array}{c}1969-1970 \\
1973-1980 \\
2000-2004\end{array}$ \\
\hline 32 & Pike Creek Tributary near Poplar Bluff, Mo. & 07063200 & 391730 & 931654 & 1955-1969 \\
\hline 33 & Turkey Creek near Joplin, Mo. & 07186600 & 390716 & 943455 & 1964-1972 \\
\hline 34 & Osage Creek near Elm Springs, Ark. & 07195000 & 391318 & 941717 & $\begin{array}{c}1950-1979 \\
1996-2008\end{array}$ \\
\hline 35 & Sager Creek near West Siloam Springs, Okla. & 07195865 & 391206 & 943618 & $1997-2008$ \\
\hline
\end{tabular}


final list of 35 streamgages for streamgage frequency analyses (table 1). Criteria used for the selection of streamgages included: (1) streamgage record length of 9 years or greater; (2) urbanization with development resulting in an increase in impervious area within the upstream basin had to exist, relative to original basin condition, and be relatively stable during the data-collection period; (3) no major diversions into or out of the basin upstream from the streamgage; (4) minimal storage effects from retention, detention structures, or road crossings; and (5) computed annual peak flows from stable ratings with sufficient measurements to define the rating adequately. Streamgage data were retrieved from the USGS National Water Information System (NWIS) at http://nwis.waterdata. usgs.gov/usa/nwis/peak. The annual peak flows for all potential streamgages were retrieved and evaluated for accuracy and length of record. Aerial imagery from local sources and/or the USGS digital orthophoto quarter-quadrangles were used to evaluate basins for urbanization and possible storage or retention of floodwaters.

Spatial distribution of the 35 USGS streamgages is shown in figure 2. The largest concentration of streamgages is located in St. Louis County (fig. 2) in eastern Missouri with 15 of the 35 streamgages in the study. Five streamgages located outside of Missouri were included because the basins upstream from the streamgages were similar to basins in Missouri, and to potentially improve the range of independent variables in the regression equations. Pertinent information such as the streamgage name, number, location, and period of record is provided in table 1 . Most streamgages had 10 to 12 years of data. The longest period of record was Blue River at Kansas City, Missouri, with 70 years of record.

\section{Flood-Frequency Analyses}

Flood-frequency estimates provided in this report were computed from an annual series of peak flow data for the streamgages according to methods recommended in Bulletin 17B by the Hydrology Subcommittee of Interagency Advisory Committee on Water Data (IACWD) in 1982. Flood-frequency estimates often are expressed as T-year discharges, where T is the recurrence interval representing the average number of years between occurrences of a discharge greater than a given magnitude. Flood-frequency estimates also can be expressed in terms of exceedance probabilities, which are the reciprocals of the recurrence intervals. Exceedance probability can further be expressed as a percentage, and a particular flood-frequency estimate can then be termed "P-percent chance discharge", where $P$ is the probability, expressed as a percentage, that the discharge will be exceeded in any year. For example, a 100year flood discharge is the same as a discharge having a 0.01 annual exceedance probability; this flood discharge also can be termed a 1-percent chance flood discharge. Because the T-year expression often is misinterpreted, this report will present the flood-frequency estimates as percent annual exceedance probabilities.
The IACWD recommends determining the floodfrequency distributions by fitting a log-Pearson Type III frequency distribution to the logarithms of the annual peak flows (Interagency Advisory Committee on Water Data, 1982). Fitting the distribution requires calculating the mean, standard deviation, and skew coefficient of the logarithms of the annual peak-flow series. The mean, standard deviation, and skew coefficient describe the mid-point, slope, and curvature of the peak-flow frequency curve, respectively. Estimates of the P-percent chance flood peaks are computed by inserting the three statistics of the frequency distribution into the equation:

$$
X=\bar{X}+K S
$$

where:

$X \quad$ is the logarithm of the magnitude of a given annual exceedance probability peak flow, in cubic feet per second;

$\bar{X} \quad$ is the mean of the logarithms of the annual peak flows;

$K \quad$ is an integration factor based on the skew of the logarithms and the given annual exceedance probability, and is tabulated in Bulletin 17B (Interagency Advisory Committee on Water Data, 1982); and,

$S \quad$ is the standard deviation of the logarithms, and is a measure of the variation of the peaks about the mean.

The skew coefficient is a measure of the asymmetry of the frequency distribution and is strongly affected by the presence of high or low outliers (annual peaks that are substantially higher or lower than other peaks in the series). Large positive skews typically are the result of high outliers, and large negative skews typically are the result of low outliers.

Following the Bulletin 17B method, a conditional probability adjustment is to be applied when low outliers are detected to improve the fit of the frequency curve to the log-Pearson Type III distribution (Interagency Advisory Committee on Water Data, 1982). When high outliers are detected and historical information on flood magnitudes outside the systematic record are available, appendix 6 of Bulletin 17B outlines a method for applying a historical adjustment. If additional historical information is not available, high outliers simply are treated as part of the systematic record, and no further adjustments are made. The expected moments algorithm (EMA) is an updated method for fitting the frequency curve that has been shown to be a more effective means of incorporating historical and paleoflood information into a flood-frequency analysis. EMA is consistent with Bulletin 17B in that it fits a log-Pearson Type III distribution using the method of moments. When historical information is absent, EMA results are indistinguishable from standard Bulletin 17B methods. The algorithm uses an iterated least-squares method for fitting regression models to censored data. From a user's perspective, the key difference in using EMA is that data can be represented using intervals rather than a single value. For example, 


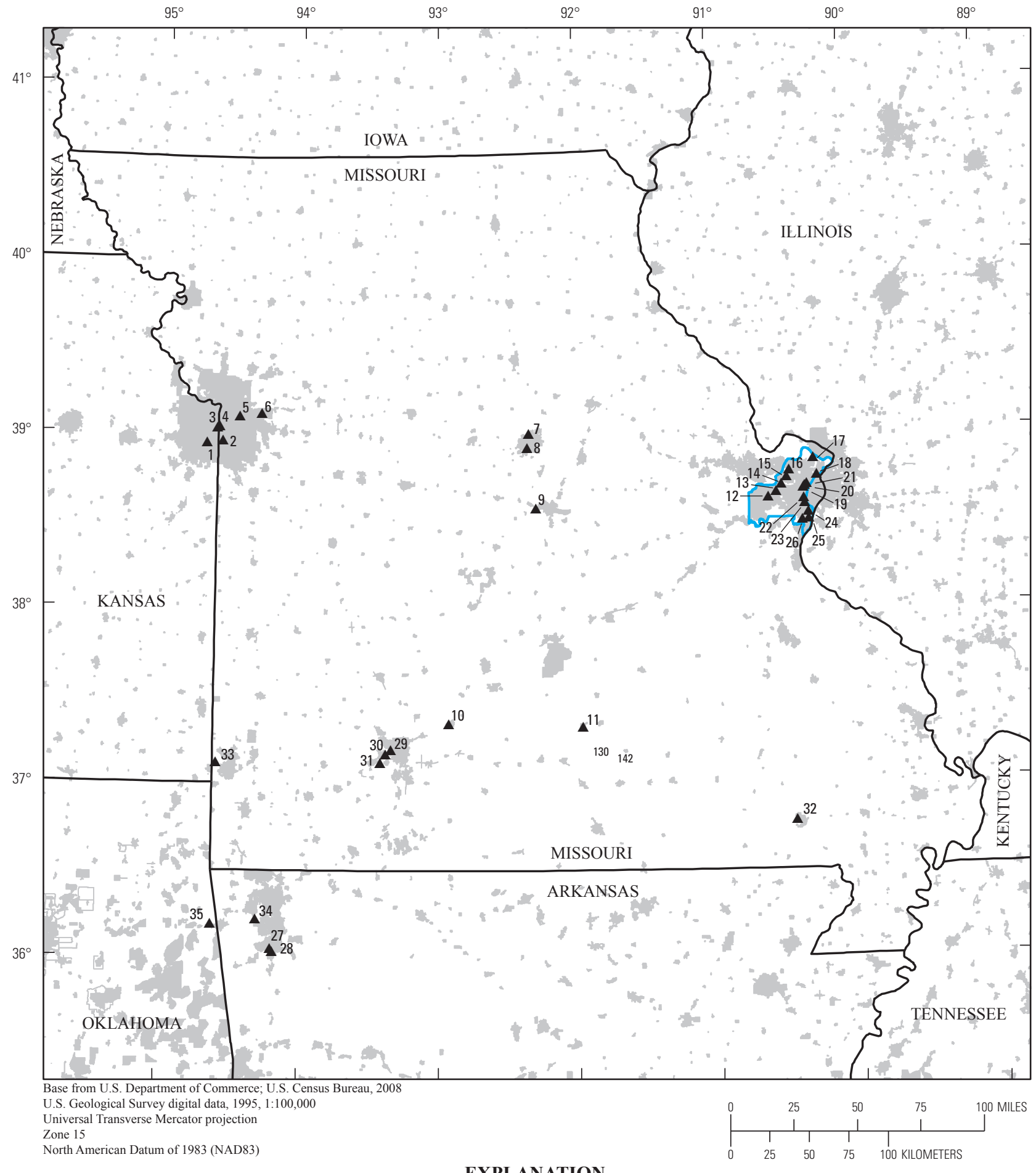

EXPLANATION

Urban area

$\Delta 1$ U.S. Geological Survey streamgage and site number (tables 1-5; table 11)

Figure 2. Location of streamgages in and adjacent to Missouri used in this study. 
if information on a historical flood is limited to the knowledge that it was larger than any peak in the systematic record, this flood can be represented as having a magnitude between the largest peak in the systematic record and infinity. During a period outside of the systematic record, there may be evidence that flood levels never exceeded a level that would have overtopped a bridge or other road. In these years, the annual peaks can be represented as having a magnitude between zero and the value that would overtop the road. Low outliers also may be represented as an interval so that they do not distort the upper tail of the frequency curve. A complete description and application of the algorithm is given in Cohn and others, (1997). Computation of the confidence intervals for the EMA flood quantile estimates is given in Cohn and others, (2001).

The detection of high outliers may lead to an historical adjustment, whereby the annual peaks are assumed to apply to a period longer than the period of systematic data collection, and peaks are assigned weightings based on their magnitudes relative to a high threshold value. The assignment of a longer historic period is based on examination of longer flood records for nearby similar streamgages. For example, if a major flood is identified as a high outlier, the short historic period at the streamgage of interest might be extended to encompass the period during which a flood of similar rarity was experienced at a nearby streamgage having a longer period of record. The detection of low outliers may lead to deletion of the peaks lower than the low threshold and necessitate a probability adjustment. Detection of outliers and adjustment of the peak data are described in Bulletin 17B, appendix 6 (Interagency Advisory Committee on Water Data, 1982).

The USGS computer program PEAKFQ was used to compute the flood-frequency estimates for streamgages presented in this report (Flynn and others, 2006). PEAKFQ automates many of the analyses procedures recommended in Bulletin 17B, including identifying and adjusting for high and low outliers and historical periods, and fitting the log-Pearson, Type III distribution to the streamflow data. The PEAKFQ program also applies the EMA procedure. The PEAKFQ program and associated documentation are available at $h t t p: / /$ water.usgs.gov/software/peakfq.html.

The EMA technique was applied to sites 3 and 4, which are located on the same stream in Kansas City, Missouri (fig. 2). The period of record for site 3 is from water years 1971 to 1982 and 1999, and the period of record for site 4 is from water years 1999 to 2008 (table 1). The large flood of 1977 was part of the systematic record for site 3; however, site 4 was not in operation in 1977. In 1999, another large flood occurred on the stream and at site 4 the annual peak is part of the systematic record. A historical peak flow was obtained at site 3 for the 1999 flood. Using EMA techniques and the 1977 and 1999 peak discharges as threshold values, the historical record length (including the systematic period) was extended from 12 years to 47 years at site 3 . The historical record length for site 4 also was extended to 31 years from 10 years of available systematic record.
The process generally followed in this study when computing flood-frequency estimates for streamgages consists of the following steps:

1. Retrieve the annual time series of peak flows for the streamgage from the USGS NWIS-Web on-line database at http://nwis.waterdata.usgs.gov/usa/nwis/ peak;

2. Compare the time series of the streamgage to the time series for upstream and downstream streamgages, and for streamgages in adjacent basins to determine if the records for the other streamgages can be used as the basis for a historical adjustment;

3. Consult the USGS Water Science Center for the state in which the streamgage is located, do a literature search, or both, to obtain any information that can be used as a basis for historical adjustments;

4. Plot the annual time series to find unusual observations that will require further investigation and to visually detect monotonic or step trends;

5. Run the Kendall's tau test on the time series of each streamgage to determine if monotonic trends are statistically significant (Helsel and Hirsch, 1992);

6. Evaluate the data for trends to make adjustments to the time series data for trends or eliminate the streamgage from further analyses;

7. Run PEAKFQ, applying any necessary historical adjustments, to obtain initial flood-frequency estimates for the streamgage. Use at-site streamgage skews for urban streamgages if a generalized regional skew is not available;

8. Plot the initial flood-frequency curve to determine if it adequately fits the annual peak data, or if low- or high-outlier thresholds or other adjustments need to be made for the curve to better fit the data;

9. Run the PEAKFQ analyses with Bulletin 17B procedures or run the EMA within PEAKFQ for streamgages with historical data to improve the fit of the frequency curve to the annual peak data; and

10. If necessary, re-run PEAKFQ to apply any adjustments to obtain a satisfactory flood-frequency curve.

\section{Basin Characteristics}

Basin characteristics were selected for use as potential independent variables in the regression analyses on the basis of their theoretical relation to flood flows, results of previous studies in similar hydrologic regions, and the ability to measure the basin characteristics using digital datasets and GIS technology. The ability to measure the basin characteristics by 
using GIS methods was important to facilitate eventual automation of the process for measuring the basin characteristics and solving the regression equations for ungaged sites.

The most common basin characteristic present in existing urban flood frequency equations is drainage area. GIS algorithms and a Digital Elevation Model (DEM) were used to delineate the drainage area basin characteristic for a gaged site. The State of Missouri has a 10-meter resolution DEM available for hydrologic analyses. The DEM data and associated documentation area are available at $h t t p: / / m s d i s . m i s s o u r i$. edu/data/10mDEM/10mDEM.htm. In general, the 10-meter DEM was based on 1:24000 scale hypsography, spot elevations, and the National Hydrography Data (NHD) dataset. If higher resolution or more accurate elevation data existed for an urban area, these data superseded the 10-meter data set. The boundary and the resulting drainage area were computed for all 35 streamgages in this study.

As a means of quality assurance, the drainage areas computed by using the GIS were compared to drainage area values in the USGS NWIS-WEB on-line database for the streamgages. Also, drainage area boundaries were compared to basin boundaries obtained from the communities. Flow patterns within a basin may change to improve stormwater runoff characteristics and direct flow away from buildings or towards drainage structures. The changes to flow patterns sometimes occur along basin boundaries and may not be represented on older datasets. The measured and published drainage areas agreed within 5 percent for most streamgages with few exceptions. For most of the exceptions, the published drainage areas were determined from older topographic maps with 10- or 20 - $\mathrm{ft}$ contour intervals dating back more than 30 years. Where exceptions did occur, the drainage areas determined using GIS techniques and more accurate elevation data were considered superior in accuracy to the previously published data. The drainage areas shown in table 2 are those determined for this study using GIS techniques.

A literature review of existing urban flood frequency studies indicated the second most commonly used variable in urban flood frequency equations after drainage area was impervious area, followed by a basin development factor, main channel slope, basin storage, and the 2-hour 2-year rainfall. Several other basin characteristics have been included in specific studies, but not repeated in other studies. The computation of the basin characteristics digitally using GIS technology precluded the basin development factor from consideration in this study because of the need to define the amount of channel improvements, channel linings, storm drains, and curbs and gutters on streets. Few, if any, GIS layers currently (2009) available include this type of information. Main channel slope along with mean basin slope were computed for each streamgage. Less than 10 percent of the drainage area was affected by storage structures for any given basin included in this study; thus, basin storage characteristic was not computed for each streamgage. The 2-hour 2-year rainfall variability for Missouri was less than 0.5 inch across the state, and also was not computed for the study basins.
The four basin characteristics calculated for this study for possible inclusion into the urban regression equations were: (1) drainage area, (2) main channel slope, (3) mean basin slope, and (4) percent impervious area. Other characteristics evaluated for potential inclusion into the regression equations were housing density (U.S. Census, 2001), mean annual rainfall (Missouri Climate Center, 2009), average channel conditions, and bank-full channel conveyance. Mean annual rainfall had minimal variability in Missouri. Average channel conditions, bank-full channel conveyance data were unavailable digitally for the basins used in this study and were not computed.

The resolution of the data sets did not bias the results of the drainage area computations. The statewide 10-meter DEM represented the basin boundary accurately compared to higher resolution data sets when urbanization did not exist along the boundaries; however, where basin boundaries were changed because of urbanization, the higher resolution elevation data sets reflected the changes more accurately. The higher resolution data sets were more accurate primarily because they were developed after the urbanization had occurred and their resulting digital elevation models consisted of smaller grid cells than the 10-meter DEM for the state.

The main channel slope was measured in feet per mile and computed as the difference in elevation between the 10and 85-percent points along the stream channel divided by the length between those two points. Mean basin slope was measured by computing the mean of the slope grid values of the DEM used in the drainage area computations. Percent impervious area was computed from the National Land Cover Dataset (NLCD) 2001 impervious area at the following link: http://www.mrlc.gov/mrlc2k_nlcd.asp. The USGS Land Cover Institute (LCI) has developed a tool to retrieve the impervious area data from the 2001 NLCD based on a predetermined basin boundary that can be uploaded to their Web site http:// lcat.usgs.gov/lcat2/. Percent impervious area was determined by computing the mean of the percent impervious area of all grid cells within the study basin from the NLCD 2001 data. The NLCD 2001 percent impervious area measurements were compared to impervious area calculated from high-resolution impervious area GIS data available for some urban areas. The correlation coefficient from the national data set and the local data sets was 0.99. Because the NLCD 2001 impervious area data are available for all urban areas in the state, these data were used to compute the impervious area for the urban basins used in this study. The percentage of impervious area from the NLCD 2001 dataset was adjusted based on historical imagery and 7.5-minute topographic maps for any basins that had undergone substantial development since the peak flow data were collected. Of the 35 streamgages in the study, 8 streamgages had impervious area computations from the NLCD 2001 dataset adjusted. The NLCD data was lowered from 1 to 23 percent at the 8 streamgages. The percent impervious area shown in table 2 for each streamgage is the adjusted value for the period of streamgage data collection. 
Table 2. Basin characteristics of streamgages in urban areas in and adjacent to Missouri used in the development of urban regression equations.

[USGS, U.S. Geological Survey; $\mathrm{mi}^{2}$, square miles]

\begin{tabular}{|c|c|c|c|c|}
\hline $\begin{array}{c}\text { Site } \\
\text { number } \\
\text { (fig. 2) }\end{array}$ & Streamgage name & $\begin{array}{c}\text { USGS } \\
\text { streamgage } \\
\text { number }\end{array}$ & $\begin{array}{c}\text { Drainage } \\
\text { area } \\
\left(\mathrm{mi}^{2}\right)\end{array}$ & $\begin{array}{c}\text { Impervious } \\
\text { area' }^{1} \\
\text { (percent) }\end{array}$ \\
\hline 1 & Indian Creek at Overland Park, Kan. & 06893300 & 26.5 & 36.3 \\
\hline 2 & Blue River at Kansas City, Mo. & 06893500 & 184 & 16.8 \\
\hline 3 & Brush Creek at Kansas City, Mo. & 06893560 & 15.6 & 32.7 \\
\hline 4 & Brush Creek at Rockhill Road in Kansas City, Mo. & 06893562 & 18.1 & 33.1 \\
\hline 5 & Rock Creek at Independence, Mo. & 06893600 & 4.97 & 31.2 \\
\hline 6 & Little Blue River near Lake City, Mo. & 06894000 & 189 & 14.1 \\
\hline 7 & Cow Branch near Columbia, Mo. & 06910200 & 1.17 & 8.48 \\
\hline 8 & Hinkson Creek at Columbia, Mo. & 06910230 & 70.3 & 5.15 \\
\hline 9 & Dickerson Creek Tributary near Jefferson City, Mo. & 06910430 & .51 & 2.33 \\
\hline 10 & Niangua Branch at Marshfield, Mo. & 06923000 & .77 & 14 \\
\hline 11 & Coyle Branch at Houston, Mo. & 06929000 & 1.1 & 11.5 \\
\hline 12 & Shotwell Creek at Highway 340 near Ellisville, Mo. & 06935800 & .76 & 25.2 \\
\hline 13 & Creve Coeur Creek at Chesterfield, Mo. & 06935850 & 6.49 & 29.5 \\
\hline 14 & Creve Coeur Creek near Creve Coeur, Mo. & 06935890 & 22.2 & 26 \\
\hline 15 & Fee Fee Creek near Bridgeton, Mo. & 06935955 & 11.7 & 39.8 \\
\hline 16 & Cowmire Creek at Bridgeton, Mo. & 06935980 & 3.41 & 42.3 \\
\hline 17 & Coldwater Creek near Black Jack, Mo. & 06936475 & 41 & 40 \\
\hline 18 & Maline Creek at Bellefontaine Neighbors, Mo. & 07005000 & 23.8 & 32.8 \\
\hline 19 & River Des Peres near University City, Mo. & 07010022 & 8.74 & 43.5 \\
\hline 20 & River Des Peres Trib. at Pagedale, Mo. & 07010030 & 1.93 & 26.5 \\
\hline 21 & Engelholm Creek near Wellston, Mo. & 07010035 & 1.47 & 27.3 \\
\hline 22 & Deer Creek at Maplewood, Mo. & 07010086 & 36.3 & 31.6 \\
\hline 23 & MacKenzie Creek near Shrewsbury, Mo. & 07010090 & 3.51 & 35.5 \\
\hline 24 & Gravois Creek near Mehlville, Mo. & 07010180 & 18.2 & 37.2 \\
\hline 25 & Martigney Creek near Arnold, Mo. & 07010208 & 2.25 & 37.7 \\
\hline 26 & Mattese Creek near Mattese, Mo. & 07019317 & 7.89 & 39.4 \\
\hline 27 & Town Branch at B.R. 62 at Fayetteville, Ark. & 07048480 & .84 & 33.6 \\
\hline 28 & Town Branch Tributary at Highway 16 at Fayetteville, Ark. & 07048490 & 1.29 & 35.7 \\
\hline 29 & Wilson Creek at Springfield, Mo. & 07052000 & 19.5 & 46 \\
\hline 30 & Wilson Creek near Springfield, Mo. & 07052100 & 35.3 & 35.6 \\
\hline 31 & Wilson Creek near Battlefield, Mo. & 07052160 & 58.4 & 17.8 \\
\hline 32 & Pike Creek Tributary near Poplar Bluff, Mo. & 07063200 & .28 & 7.94 \\
\hline 33 & Turkey Creek near Joplin, Mo. & 07186600 & 42.3 & 13 \\
\hline 34 & Osage Creek near Elm Springs, Ark. & 07195000 & 129.7 & 8.67 \\
\hline 35 & Sager Creek near West Siloam Springs, Okla. & 07195865 & 19.5 & 8.35 \\
\hline
\end{tabular}

${ }^{1}$ Impervious area used in the regression equations for period of streamgage data collection. 


\section{Regionalization}

Physical features within a state or region can have a pronounced effect on the flood frequency characteristics of a basin (Alexander and Wilson, 1995). (Urban areas located in distinctively different regions such as in wide meandering flood plains with low to moderate valley slopes or in narrow flood plains with sharp, well- defined ridges with moderate to high slopes may result in bias in the residuals from regression results when all streamgages are included in the analyses.) Evaluation of possible biases in the regression analyses was considered in this study to define distinct regions.

\section{Estimation Of The Magnitude And Frequency Of Floods}

The Interagency Advisory Committee on Water Data (1982) recommends that the log-Pearson Type III distribution be used as the standard flood-frequency technique for Federal planning involving water and related land resources. This technique uses the method of moments to relate the annual maximum discharge data to selected frequencies. For this study, the frequencies reported for hydrologically similar regions are the 50-, 20-, 10-, 4-, 2-, 1-, and 0.2-percent annual exceedance probabilities.

\section{Definition of Regions}

The number and spatial distribution of the streamgages in this study limited the definition of separate hydrologic regions for the state. Additional streamgages outside of Missouri were used to supplement the Missouri streamgages to increase the range of applicability of the regression equations for urban areas throughout the state. [The residuals from the ordinary least-squares (OLS) analyses were plotted on a state map.] The residuals are the differences between the streamgage flood-frequency data and the corresponding OLS regression equation results (see Model Development Section). The magnitude and numerical sign of the residuals were checked for possible regional biases. Overall, no geographic bias existed in the results. OLS analyses residuals also were plotted in relation to drainage area and impervious area for the 50-, 10-, and 1-percent annual exceedance probabilities (fig. 3). The residual plots of figure 3 were used as a diagnostic tool for the regression equations. The random scatter of the points above and below the zero reference line indicates that the model is satisfactorily meeting the assumptions of multiple-linearregression techniques. Additional plots were done with the 50-, 10-, and 1-percent annual exceedance probabilities for the observed peak flows and the estimated peak flows (fig 4). These plots were used to evaluate the regression equations for potential climatic and temporal bias. Results of these plots indicated no climatic or temporal bias existed in the data.

\section{Model Development}

Regression equations were developed for use in estimating peak flows with selected annual exceedance probabilities of 50 to 0.2 percent at gaged and ungaged locations for urban areas within the state of Missouri. OLS regression techniques were used to select the basin characteristics used as the independent variables. Linear relations between the independent variables and the dependent variable are required for OLS regression. To satisfy this criterion, variables often are transformed, and in hydrologic analyses typically the base10 logarithm transformation is used. The dependent variable, flood-peak discharge, was transformed to logarithms before the regression analyses. The independent variables of drainage area, main channel slope, and mean basin slope also were transformed to logarithms (base 10); however, the independent variable percent impervious area was not transformed.

Homoscedasticity (a constant variance in the dependent variable over the range of the independent variables) about the regression line and normality of residuals also are criteria for OLS regression. Transformation of the flow data and certain other variables to logarithms often enhances the homoscedasticity of the data about the regression line. Linearity, homoscedasticity, and normality of residuals were examined in residual plots.

The hydrologic model used in the regression analysis is of the form:

$$
Q_{T}=a A^{b} B^{c} 10^{d C},
$$

where

$$
\begin{aligned}
& Q_{T} \quad \text { is the dependent variable, a flood discharge } \\
& \text { having a given annual exceedance } \\
& \text { probability of } \mathrm{T} \text {, in cubic feet per second; } \\
& A \text {, } B \text { are base-10 logarithm, transformed } \\
& \text { independent variables (basin } \\
& \text { characteristics); } \\
& \text { C is an untransformed independent variable } \\
& \text { (basin characteristic); }
\end{aligned}
$$

and

$a, b, c, d \quad$ are regression coefficients.

If the dependent variable $Q_{T}$ and the independent variables $A$ and $B$ are logarithmically transformed and the independent variable, $C$, untransformed then the hydrologic model has the following linear form:

$$
\log Q_{T}=\log a+b(\log A)+c(\log B)+d(C)+\ldots
$$

where the variables are as previously defined. A combination of the arithmetic and logarithmic relation was used in this investigation because the impervious area variable was used as a percentage and the resulting logarithmic transformation did not improve the linear relation with the dependent variable, $Q_{T}$.

The independent variables of drainage area, impervious area, main channel slope, and mean basin slope were included 

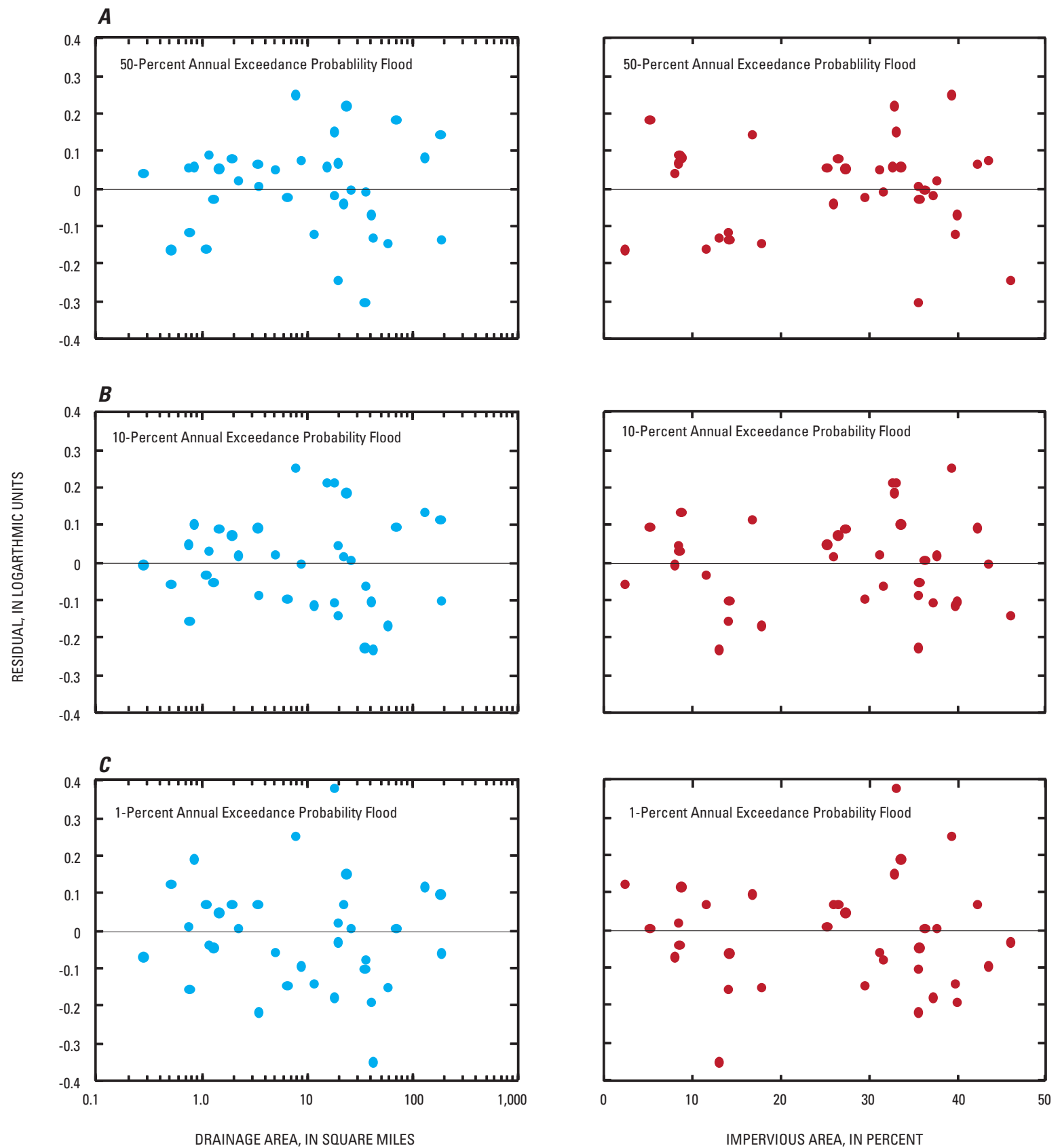

Figure 3. Residuals of the regression equations for estimating the magnitude of the $(A) 50-$-, $(B)$ 10-, and $(C) 1$-percent annual exceedance probability flood in relation to drainage area and percent impervious area. 

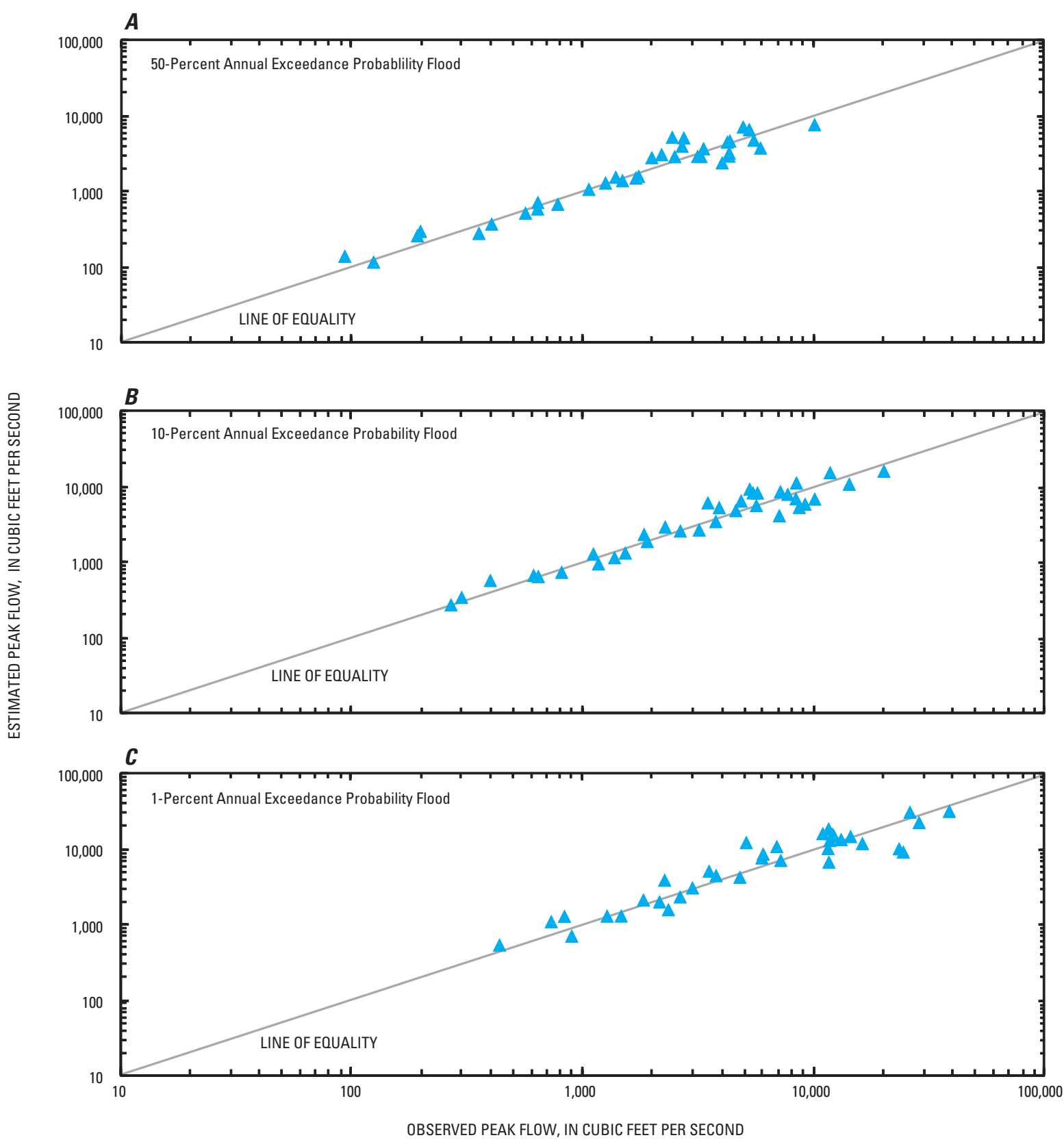

Figure 4. Comparison of observed and estimated peak flows of the $(A) 50-,(B) 10-$, and $(C)$ 1-percent annual exceedance probability flood.

in the OLS regression analyses. The OLS results were evaluated on the basis of Mallow's $C p$ statistic, the adjusted coefficient of determination $\left(R^{2}\right)$, and the statistical significance of the independent variables at the 95-percent confidence level.

Statistically significant variables were tested for multicollinearity using the variance inflation factor. The basin characteristics selected were determined to not be affected by multicollinearity. The affect of individual streamgages on the regression coefficients was measured by the statistical test Cook's $D$ (Cook, 1977). The test indicated no individual streamgages had an undue affect on the regression results.
The statistical parameters used to fit the log-Pearson Type III distribution to the observed annual peak flows for each streamgage are the mean of the logarithms, standard deviation of the logs, and skew of the logarithms (table 3). These fitting parameters describe the mid-point, slope, and curvature of the peak-flow frequency curve, respectively. The skew of the logarithms is positive when the mean of the peak flows exceeds the median value and negative when the mean is less than the median. Peak flows that are substantially higher or lower than other peaks in the annual series are considered outliers, and these peak flows strongly affect the skew parameter. Streamgages with peak flow outliers were processed using the 
Table 3. Flood-frequency statistics for annual peak flow data from 35 U.S. Geological Survey streamgages in urban areas in and adjacent to Missouri.

[USGS, U.S. Geological Survey]

\begin{tabular}{|c|c|c|c|c|c|}
\hline \multirow[b]{2}{*}{$\begin{array}{c}\text { Site } \\
\text { number } \\
\text { (fig. 2) }\end{array}$} & \multirow[b]{2}{*}{ Streamgage name } & \multirow[b]{2}{*}{$\begin{array}{c}\text { USGS } \\
\text { streamgage } \\
\text { number }\end{array}$} & \multicolumn{3}{|c|}{ Statistical data for water-year peak flows } \\
\hline & & & $\begin{array}{c}\text { Mean } \\
\text { (logarithm) }\end{array}$ & $\begin{array}{c}\text { Standard } \\
\text { deviation } \\
\text { (logarithm) }\end{array}$ & $\begin{array}{l}\text { Skew of } \\
\text { logarithms }\end{array}$ \\
\hline 1 & Indian Creek at Overland Park, Kan. & 06893300 & 3.634 & 0.196 & 0.212 \\
\hline 2 & Blue River at Kansas City, Mo. & 06893500 & 4.019 & .220 & .367 \\
\hline 3 & Brush Creek at Kansas City, Mo. & 06893560 & 3.528 & .299 & .605 \\
\hline 4 & Brush Creek at Rockhill Road in Kansas City, Mo. & 06893562 & 3.683 & .211 & 1.382 \\
\hline 5 & Rock Creek at Independence, Mo. & 06893600 & 3.151 & .227 & -.579 \\
\hline 6 & Little Blue River near Lake City, Mo. & 06894000 & 3.711 & .277 & .312 \\
\hline 7 & Cow Branch near Columbia, Mo. & 06910200 & 2.505 & .270 & -.370 \\
\hline 8 & Hinkson Creek at Columbia, Mo. & 06910230 & 3.634 & .228 & -.011 \\
\hline 9 & Dickerson Creek Tributary near Jefferson City, Mo. & 06910430 & 1.993 & .365 & .436 \\
\hline 10 & Niangua Branch at Marshfield, Mo. & 06923000 & 2.289 & .240 & .124 \\
\hline 11 & Coyle Branch at Houston, Mo. & 06929000 & 2.292 & .389 & -.091 \\
\hline 12 & Shotwell Creek at Highway 340 near Ellisville, Mo. & 06935800 & 2.584 & .265 & -.466 \\
\hline 13 & Creve Coeur Creek at Chesterfield, Mo. & 06935850 & 3.150 & .159 & .262 \\
\hline 14 & Creve Coeur Creek near Creve Coeur, Mo. & 06935890 & 3.408 & .266 & .198 \\
\hline 15 & Fee Fee Creek near Bridgeton, Mo. & 06935955 & 3.338 & .201 & -.144 \\
\hline 16 & Cowmire Creek at Bridgeton, Mo. & 06935980 & 3.227 & .226 & -.415 \\
\hline 17 & Coldwater Creek near Black Jack, Mo. & 06936475 & 3.710 & .177 & -.417 \\
\hline 18 & Maline Creek at Bellefontaine Neighbors, Mo. & 07005000 & 3.777 & .177 & .184 \\
\hline 19 & River Des Peres near University City, Mo. & 07010022 & 3.509 & .123 & -.185 \\
\hline 20 & River Des Peres Trib. at Pagedale, Mo. & 07010030 & 2.893 & .227 & .027 \\
\hline 21 & Engelholm Creek near Wellston, Mo. & 07010035 & 2.770 & .309 & -.665 \\
\hline 22 & Deer Creek at Maplewood, Mo. & 07010086 & 3.658 & .150 & .777 \\
\hline 23 & MacKenzie Creek near Shrewsbury, Mo. & 07010090 & 3.078 & .161 & -.790 \\
\hline 24 & Gravois Creek near Mehlville, Mo. & 07010180 & 3.533 & .117 & .459 \\
\hline 25 & Martigney Creek near Arnold, Mo. & 07010208 & 3.024 & .201 & -.088 \\
\hline 26 & Mattese Creek near Mattese, Mo. & 07019317 & 3.610 & .188 & .158 \\
\hline 27 & Town Branch at B.R. 62 at Fayetteville, Ark. & 07048480 & 2.771 & .225 & .502 \\
\hline 28 & Town Branch Tributary at Highway 16 at Fayetteville, Ark. & 07048490 & 2.816 & .176 & .333 \\
\hline 29 & Wilson Creek at Springfield, Mo. & 07052000 & 3.459 & .226 & .538 \\
\hline 30 & Wilson Creek near Springfield, Mo. & 07052100 & 3.420 & .228 & .834 \\
\hline 31 & Wilson Creek near Battlefield, Mo. & 07052160 & 3.451 & .218 & .546 \\
\hline 32 & Pike Creek Tributary near Poplar Bluff, Mo. & 07063200 & 2.068 & .297 & -.514 \\
\hline 33 & Turkey Creek near Joplin, Mo. & 07186600 & 3.286 & .208 & -.288 \\
\hline 34 & Osage Creek near Elm Springs, Ark. & 07195000 & 3.726 & .345 & -.280 \\
\hline 35 & Sager Creek near West Siloam Springs, Okla. & 07195865 & 3.231 & .270 & .005 \\
\hline
\end{tabular}


Table 4. Flood discharges at given annual exceeedance probabilities for streamgages in urban areas in and adjacent to Missouri.

$\left[\mathrm{ft}^{3} / \mathrm{s}\right.$, cubic feet per second; USGS, U.S. Geological Survey; G, estimated from the Bulletin 17B (IACWD, 1982) analyses of the streamgage; R, estimated from the regression equation; $\mathrm{W}$, weighted Bulletin 17B analyses and regression equation results]

\begin{tabular}{|c|c|c|c|c|c|c|c|c|c|c|}
\hline \multirow[b]{3}{*}{$\begin{array}{c}\text { Site } \\
\text { number } \\
\text { (fig. 2) }\end{array}$} & \multirow[b]{3}{*}{$\begin{array}{c}\text { USGS } \\
\text { streamgage } \\
\text { number }\end{array}$} & \multicolumn{9}{|c|}{ Flood discharges at percent annual exceedance probabilities ( $\left.\mathrm{ft}^{3} / \mathbf{s}\right)$} \\
\hline & & \multicolumn{3}{|c|}{50} & \multicolumn{3}{|c|}{20} & \multicolumn{3}{|c|}{10} \\
\hline & & G & $\mathbf{R}$ & $\mathbf{W}$ & $\mathbf{G}$ & $\mathbf{R}$ & $\mathbf{W}$ & G & $\mathbf{R}$ & $\mathbf{W}$ \\
\hline 1 & 06893300 & 4,240 & 4,320 & 4,310 & 6,260 & 6,160 & 6,170 & 7,750 & 7,840 & 7,840 \\
\hline 2 & 06893500 & 10,100 & 7,350 & 7,760 & 15,800 & 11,800 & 12,100 & 20,300 & 15,800 & 16,000 \\
\hline 3 & 06893560 & 3,150 & 2,800 & 2,820 & 5,850 & 4,100 & 4,140 & 8,430 & 5,260 & 5,290 \\
\hline 4 & 06893562 & 4,320 & 3,100 & 3,170 & 6,790 & 4,520 & 4,570 & 9,230 & 5,790 & 5,820 \\
\hline 5 & 06893600 & 1,490 & 1,340 & 1,340 & 2,210 & 2,000 & 2,000 & 2,650 & 2,570 & 2,570 \\
\hline 6 & 06894000 & 4,970 & 6,850 & 6,630 & 8,680 & 11,200 & 11,100 & 11,800 & 15,100 & 15,000 \\
\hline 7 & 06910200 & 332 & 271 & 273 & 544 & 479 & 481 & 690 & 646 & 647 \\
\hline 8 & 06910230 & 4,310 & 2,840 & 2,900 & 6,690 & 4,970 & 5,010 & 8,420 & 6,820 & 6,840 \\
\hline 9 & 06910430 & 93 & 135 & 134 & 195 & 251 & 251 & 298 & 342 & 342 \\
\hline 10 & 06923000 & 192 & 252 & 248 & 308 & 430 & 425 & 397 & 572 & 568 \\
\hline 11 & 06929000 & 198 & 289 & 286 & 418 & 499 & 498 & 612 & 668 & 668 \\
\hline 12 & 06935800 & 403 & 360 & 362 & 648 & 567 & 569 & 810 & 735 & 736 \\
\hline 13 & 06935850 & 1,390 & 1,490 & 1,480 & 1,910 & 2,250 & 2,240 & 2,280 & 2,900 & 2,890 \\
\hline 14 & 06935890 & 2,510 & 2,780 & 2,770 & 4,250 & 4,260 & 4,260 & 5,670 & 5,550 & 5,550 \\
\hline 15 & 06935955 & 2,200 & 2,960 & 2,900 & 3,220 & 4,140 & 4,120 & 3,910 & 5,210 & 5,170 \\
\hline 16 & 06935980 & 1,750 & 1,530 & 1,540 & 2,630 & 2,120 & 2,140 & 3,200 & 2,660 & 2,670 \\
\hline 17 & 06936475 & 5,280 & 6,310 & 6,250 & 7,270 & 8,730 & 8,680 & 8,460 & 11,000 & 10,900 \\
\hline 18 & 07005000 & 5,900 & 3,610 & 3,710 & 8,390 & 5,270 & 5,340 & 10,200 & 6,770 & 6,810 \\
\hline 19 & 07010022 & 3,260 & 2,800 & 2,840 & 4,110 & 3,820 & 3,840 & 4,620 & 4,780 & 4,770 \\
\hline 20 & 07010030 & 780 & 655 & 659 & 1,210 & 1,020 & 1,020 & 1,530 & 1,320 & 1,320 \\
\hline 21 & 07010035 & 638 & 570 & 571 & 1,080 & 882 & 884 & 1,370 & 1,140 & 1,140 \\
\hline 22 & 07010086 & 4,350 & 4,480 & 4,470 & 5,960 & 6,580 & 6,560 & 7,210 & 8,470 & 8,450 \\
\hline 23 & 07010090 & 1,260 & 1,250 & 1,250 & 1,640 & 1,820 & 1,810 & 1,850 & 2,310 & 2,290 \\
\hline 24 & 07010180 & 3,340 & 3,540 & 3,520 & 4,240 & 5,020 & 4,980 & 4,870 & 6,380 & 6,340 \\
\hline 25 & 07010208 & 1,060 & 1,030 & 1,030 & 1,560 & 1,480 & 1,480 & 1,900 & 1,870 & 1,870 \\
\hline 26 & 07019317 & 4,030 & 2,310 & 2,380 & 5,840 & 3,240 & 3,290 & 7,130 & 4,090 & 4,120 \\
\hline 27 & 07048480 & 565 & 500 & 502 & 896 & 744 & 746 & 1,170 & 946 & 947 \\
\hline 28 & 07048490 & 639 & 691 & 688 & 912 & 1,010 & 1,010 & 1,110 & 1,280 & 1,280 \\
\hline 29 & 07052000 & 2,750 & 4,920 & 4,840 & 4,380 & 6,560 & 6,530 & 5,740 & 8,160 & 8,140 \\
\hline 30 & 07052100 & 2,450 & 5,010 & 4,860 & 3,950 & 7,150 & 7,080 & 5,300 & 9,130 & 9,090 \\
\hline 31 & 07052160 & 2,700 & 3,810 & 3,760 & 4,220 & 6,130 & 6,090 & 5,480 & 8,160 & 8,130 \\
\hline 32 & 07063200 & 124 & 113 & 113 & 210 & 203 & 203 & 268 & 273 & 273 \\
\hline 33 & 07186600 & 1,980 & 2,690 & 2,670 & 2,910 & 4,490 & 4,460 & 3,510 & 6,040 & 6,000 \\
\hline 34 & 07195000 & 5,520 & 4,580 & 4,620 & 10,500 & 7,810 & 7,880 & 14,400 & 10,600 & 10,700 \\
\hline 35 & 07195865 & 1,700 & 1,460 & 1,460 & 2,870 & 2,530 & 2,530 & 3,780 & 3,430 & 3,430 \\
\hline
\end{tabular}


Table 4. Flood discharges at given annual exceedance probabilities for streamgages in urban areas in and adjacent to Missouri.-Continued

[ft 3 s, cubic feet per second; USGS, U.S. Geological Survey; G, estimated from the Bulletin 17B (IACWD, 1982) analyses of the streamgage; R, estimated from the regression equation; $\mathrm{W}$, weighted Bulletin $17 \mathrm{~B}$ analyses and regression equation results]

\begin{tabular}{|c|c|c|c|c|c|c|c|c|c|c|}
\hline \multirow[b]{3}{*}{$\begin{array}{c}\text { Site } \\
\text { number } \\
\text { (fig. 2) }\end{array}$} & \multirow[b]{3}{*}{$\begin{array}{c}\text { USGS } \\
\text { streamgage } \\
\text { number }\end{array}$} & \multicolumn{9}{|c|}{ Flood discharges at percent annual exceedance probabilities ( $\left.\mathrm{ft}^{3} / \mathrm{s}\right)$} \\
\hline & & \multicolumn{3}{|c|}{4} & \multicolumn{3}{|c|}{2} & \multicolumn{3}{|c|}{1} \\
\hline & & $\mathbf{G}$ & $\mathbf{R}$ & $\mathbf{W}$ & $\mathbf{G}$ & $\mathbf{R}$ & $\mathbf{W}$ & G & $\mathbf{R}$ & $\mathbf{W}$ \\
\hline 1 & 06893300 & 9,800 & 9,340 & 9,350 & 11,400 & 11,700 & 11,700 & 13,200 & 13,100 & 13,100 \\
\hline 2 & 06893500 & 26,900 & 20,800 & 20,900 & 32,500 & 26,300 & 26,400 & 38,700 & 31,000 & 31,100 \\
\hline 3 & 06893560 & 12,800 & 6,360 & 6,390 & 17,200 & 7,940 & 7,970 & 22,600 & 8,930 & 8,970 \\
\hline 4 & 06893562 & 13,500 & 6,990 & 7,010 & 17,900 & 8,730 & 8,750 & 23,500 & 9,820 & 9,840 \\
\hline 5 & 06893600 & 3,160 & 3,110 & 3,110 & 3,500 & 3,860 & 3,860 & 3,810 & 4,340 & 340 \\
\hline 6 & 06894000 & 16,800 & 20,100 & 20,000 & 21,100 & 25,400 & 25,300 & 26,200 & 30,100 & 30,000 \\
\hline 7 & 06910200 & 875 & 862 & 86 & 1,010 & 1,060 & 1,060 & 1,150 & 1,250 & 1,250 \\
\hline 8 & 06910230 & 10,800 & 9,430 & 9,440 & 12,600 & 11,800 & 11,800 & 14,500 & 14,300 & 14,300 \\
\hline 9 & 06910430 & 482 & 468 & 468 & 669 & 574 & 574 & 906 & 683 & 683 \\
\hline 10 & 06923000 & 523 & 743 & 740 & 627 & 913 & 913 & 739 & 1,060 & 1,060 \\
\hline 11 & 06929000 & 913 & 879 & 879 & 1,180 & 1,080 & 1,080 & 1,480 & 1,260 & 1,260 \\
\hline 12 & 06935800 & 1,010 & 906 & 907 & 1,150 & 1,110 & 1,110 & 1,290 & 1,260 & 1,260 \\
\hline 13 & 06935850 & 2,770 & 3,540 & 3,530 & 3,150 & 4,400 & 4,390 & 3,550 & 4,970 & 4,960 \\
\hline 14 & 06935890 & 7,770 & 6,940 & 6,940 & 9,580 & 8,670 & 8,670 & 11,600 & 9,920 & 9,930 \\
\hline 15 & 06935955 & 4,780 & 6,090 & 6,070 & 5,430 & 7,590 & 7,560 & 6,080 & 8,390 & 8,360 \\
\hline 16 & 06935980 & 3,880 & 3,050 & 3,060 & 4,370 & 3,780 & 3,790 & 4,830 & 4,130 & 4,140 \\
\hline 17 & 06936475 & 9,840 & 13,000 & 12,900 & 10,800 & 16,200 & 16,100 & 11,700 & 18,000 & 17,900 \\
\hline 18 & 07005000 & 12,500 & 8,200 & 8,230 & 14,400 & 10,200 & 10,200 & 16,300 & 11,500 & 11,500 \\
\hline 19 & 07010022 & 5,210 & 5,480 & 5,470 & 5,620 & 6,820 & 6,790 & 6,010 & 7,470 & 7,440 \\
\hline 20 & 07010030 & 1,960 & 1,620 & 1,620 & 2,300 & 2,000 & 2,000 & 2,660 & 2,270 & 2,270 \\
\hline 21 & 07010035 & 1,720 & 1,400 & 1,400 & 1,950 & 1,720 & 1,720 & 2,170 & 1,940 & 1,940 \\
\hline 22 & 07010086 & 9,030 & 10,300 & 10,300 & 10,600 & 13,000 & 13,000 & 12,300 & 14,700 & 14,700 \\
\hline 23 & 07010090 & 2,050 & 2,740 & 2,720 & 2,180 & 3,390 & 3,370 & 2,280 & 3,770 & 3,740 \\
\hline 24 & 07010180 & 5,680 & 7,560 & 7,530 & 6,320 & 9,440 & 9,400 & 6,970 & 10,500 & 10,400 \\
\hline 25 & 07010208 & 2,340 & 2,190 & 2,190 & 2,680 & 2,700 & 2,700 & 3,010 & 2,980 & 2,980 \\
\hline 26 & 07019317 & 8,880 & 4,780 & 4,800 & 10,200 & 5,940 & 5,960 & 11,700 & 6,570 & 6,590 \\
\hline 27 & 07048480 & 1,590 & 1,120 & 1,120 & 1,950 & 1,380 & 1,380 & 2,370 & 1,530 & 1,530 \\
\hline 28 & 07048490 & 1,390 & 1,510 & 1,510 & 1,610 & 1,860 & 1,860 & 1,850 & 2,060 & 2,060 \\
\hline 29 & 07052000 & 7,820 & 9,290 & 9,290 & 9,680 & 11,600 & 11,600 & 11,800 & 12,700 & 12,700 \\
\hline 30 & 07052100 & 7,520 & 10,900 & 10,900 & 9,600 & 13,700 & 13,700 & 12,100 & 15,400 & 15,400 \\
\hline 31 & 07052160 & 7,400 & 10,600 & 10,600 & 9,080 & 13,400 & 13,400 & 11,000 & 15,600 & 15,600 \\
\hline 32 & 07063200 & 340 & 362 & 362 & 392 & 443 & 443 & 442 & 519 & 519 \\
\hline 33 & 07186600 & 4,260 & 8,030 & 7,990 & 4,800 & 10,100 & 10,000 & 5,320 & 11,900 & 11,800 \\
\hline 34 & 07195000 & 19,800 & 14,500 & 14,600 & 24,100 & 18,300 & 18,400 & 28,700 & 22,000 & 22,000 \\
\hline 35 & 07195865 & 5,060 & 4,640 & 4,640 & 6,110 & 5,800 & 5,800 & 7,250 & 6,910 & 6,910 \\
\hline
\end{tabular}


Table 4. Flood discharges at given annual exceeedance probabilities for streamgages in urban areas in and adjacent to Missouri.-Continued

$\left[\mathrm{ft}^{3} / \mathrm{s}\right.$, cubic feet per second; USGS, U.S. Geological Survey; G, estimated from the Bulletin 17B (IACWD, 1982) analyses of the streamgage; R, estimated from the regression equation; $\mathrm{W}$, weighted Bulletin 17B analyses and regression equation results]

\begin{tabular}{|c|c|c|c|c|c|c|}
\hline \multirow[b]{3}{*}{$\begin{array}{c}\text { Site } \\
\text { number } \\
\text { (fig. 2) }\end{array}$} & \multirow[b]{3}{*}{$\begin{array}{c}\text { USGS } \\
\text { streamgage } \\
\text { number }\end{array}$} & \multicolumn{3}{|c|}{ Flood discharges at percent annual exceedance probabilities $\left(\mathrm{ft}^{3} / \mathbf{s}\right)$} & \multirow{2}{*}{\multicolumn{2}{|c|}{ Maximum recorded flood }} \\
\hline & & \multicolumn{3}{|c|}{0.2} & & \\
\hline & & G & $\mathbf{R}$ & $\mathbf{W}$ & $\begin{array}{c}\text { Discharge } \\
\left(\mathrm{ft}^{3} / \mathbf{s}\right)\end{array}$ & Date \\
\hline 1 & 06893300 & 17,800 & 17,800 & 17,800 & 12,800 & $06 / 09 / 84$ \\
\hline 4 & 06893562 & 43,700 & 13,400 & 13,400 & 21,700 & $10 / 04 / 98$ \\
\hline 5 & 06893600 & 4,440 & 5,890 & 5,880 & 2,520 & $06 / 19 / 67$ \\
\hline 6 & 06894000 & 41,100 & 44,300 & 44,200 & 42,300 & $08 / 13 / 82$ \\
\hline 7 & 06910200 & 1,460 & 1,760 & 1,760 & 625 & $\begin{array}{l}07 / 18 / 58 \\
06 / 22 / 69\end{array}$ \\
\hline 10 & 06923000 & 1,040 & 1,470 & 1,460 & 605 & $06 / 20 / 77$ \\
\hline 11 & 06929000 & 2,340 & 1,770 & 1,770 & 1,030 & $06 / 30 / 51$ \\
\hline 12 & 06935800 & 1,590 & 1,700 & 1,700 & 1,030 & $08 / 09 / 70$ \\
\hline 13 & 06935850 & 4,560 & 6,790 & 6,760 & 2,820 & 09/14/08 \\
\hline 14 & 06935890 & 17,200 & 13,800 & 13,800 & 8,780 & $09 / 14 / 08$ \\
\hline 15 & 06935955 & 7,610 & 11,300 & 11,200 & 4,680 & $09 / 14 / 08$ \\
\hline 16 & 06935980 & 5,840 & 5,440 & 5,450 & 3,580 & $09 / 14 / 08$ \\
\hline 17 & 06936475 & 13,500 & 24,600 & 24,300 & 9,690 & $09 / 14 / 08$ \\
\hline 18 & 07005000 & 21,200 & 15,900 & 16,000 & 12,800 & $09 / 14 / 08$ \\
\hline 25 & 07010208 & 3,820 & 3,950 & 3,950 & 2,120 & $09 / 14 / 08$ \\
\hline 26 & 07019317 & 15,400 & 8,790 & 8,840 & 9,200 & $09 / 14 / 08$ \\
\hline 27 & 07048480 & 3,590 & 2,030 & 2,040 & 1,440 & 06/30/99 \\
\hline 28 & 07048490 & 2,470 & 2,720 & 2,720 & 1,390 & $07 / 03 / 04$ \\
\hline 29 & 07052000 & 18,100 & 16,900 & 16,900 & 6,750 & $07 / 12 / 00$ \\
\hline 30 & 07052100 & 20,200 & 21,100 & 21,100 & 6,410 & $06 / 13 / 08$ \\
\hline 31 & 07052160 & 16,600 & 22,500 & 22,500 & 7,240 & $05 / 20 / 79$ \\
\hline 32 & 07063200 & 551 & 721 & 719 & 366 & $03 / 08 / 64$ \\
\hline 33 & 07186600 & 6,500 & 17,200 & 17,000 & 3,520 & $06 / 13 / 64$ \\
\hline 34 & 07195000 & 40,100 & 32,500 & 32,600 & 22,500 & $\begin{array}{l}05 / 10 / 50 \\
05 / 19 / 61\end{array}$ \\
\hline 35 & 07195865 & 10,200 & 10,000 & 10,000 & 4,130 & $06 / 21 / 00$ \\
\hline
\end{tabular}


EMA algorithm described in the Flood-Frequency Analysis Section of this report. The final flood discharges for selected annual exceedance probabilities for each streamgage are shown in table 4, along with the maximum recorded flood.

Weighted least-squares (WLS) regression was used to compute the final regression coefficients and the measures of accuracy for the regression equations using the computer program Weighted-Multiple-Linear-Regression Model Program, WREG (Eng and others, 2009). Stedinger and Tasker (1985) compared ordinary, weighted, and generalized least-squares regression techniques. The results of their study determined that weighted and generalized regression techniques provided better estimates of the accuracy of the equations than ordinary least-squares. Improvements in the weighted equations occurred when streamflow records at streamgages are of different and varying lengths. Also, improvements were noted when concurrent flows at different streamgages were correlated. WLS techniques give less weight to streamgages that have shorter periods of record than streamgages with longer periods of record (Tasker, 1980). The results of the WLS regression analyses for the selected annual exceedance probabilities of 50-, 20-, 10-, 4-, 2-, 1-, and 0.2-percent for Missouri are given in table 5. Flood discharges for the at-site (Bulletin 17B), WLS regression, and weighted (Bulletin 17B and WLS) analyses for each selected probability are included in table 4.

The Hydrology Subcommittee of Interagency Advisory Committee on Water Data (1982) recommended that better estimates of flood-frequency statistics for a gaged station can be obtained by combining (weighting) at-site flow estimates determined from the log-Pearson Type III analysis of the annual peaks with flow estimates obtained for the station from regression equations. Optimal weighted flow estimates can be obtained if the variance of estimation for each of the two estimates is known or can be estimated accurately. The variance of estimation can be thought of as a measure of the uncertainty in either the at-site estimate or the regional regression results. If the two estimates can be assumed to be independent and are weighted in inverse proportion to the associated variances, the variance of the weighted estimate will be less than the variance of either of the independent estimates (Gotvald and others, 2009).

The variance of estimates corresponding to the at-site flow estimate from the log-Pearson Type III analysis is computed using the asymptotic formula given in Cohn and others (2001) with the addition of the mean-squared error of generalized skew (Griffis and others, 2004). This variance varies as a function of the length of record, the fitted log-Pearson Type III distribution parameters (mean, standard deviation, and weighted skew), and the accuracy of the method used to determine the generalized-skew component of the weighted skew. The variance of estimates for the at-site value generally decreases with length of record and the quality of the log-Pearson Type III distribution fit. The variance of estimate from the regional regression equations is a function of the regression equations and the values of the independent variables used to

Table 5. Weighted least-squares regression equations for streams in urban areas in Missouri.

[DRNAREA, drainage area, in square miles; IMPLNLCD01, impervious area from National Land Cover Dataset 2001, in percent]

\begin{tabular}{ccc}
\hline Percent annual exceedance probability & $\begin{array}{c}\text { Flood recurrence interval } \\
\text { (years) }\end{array}$ & Urban regression equations \\
\hline 50 & 2 & $Q_{2}=188(\mathrm{DRNAREA})^{0.599} 10^{0.014(\mathrm{IMPNLCD} 01)}$ \\
20 & 5 & $Q_{5}=352(\mathrm{DRNAREA})^{0.592} 10^{0.011(\mathrm{IMPNLCD} 01)}$ \\
10 & 10 & $Q_{10}=484(\mathrm{DRNAREA})^{0.594} 10^{0.010(\mathrm{IMPNLCD} 01)}$ \\
4 & 25 & $Q_{25}=671(\mathrm{DRNAREA})^{0.599} 10^{0.008(\mathrm{IMPNLCD} 01)}$ \\
2 & 50 & $Q_{50}=826(\mathrm{DRNAREA})^{0.604} 10^{0.008(\mathrm{IMPNLCD} 01)}$ \\
1 & 100 & $Q_{100}=991(\mathrm{DRNAREA})^{0.608} 10^{0.007(\mathrm{IMPNLCD} 01)}$ \\
& 500 & $Q_{500}=1,420(\mathrm{DRNAREA})^{0.619} 10^{0.006(\mathrm{IMPNLCD} 01)}$ \\
\hline
\end{tabular}


develop the flow estimate from the regression equations. This variance generally increases as the values of the independent variables moves further from the mean values of the independent variables.

Once the variances have been computed, the two independent flow estimates were weighted using the following: equation:

$$
\log Q_{P(g) w}=\frac{V_{p, P(g) r} \log Q_{P(g) s}+V_{p, P(g) s} \log Q_{P(g) r}}{V_{p, P(g) s}+V_{p, P(g) r}}
$$

where

$$
\begin{array}{cc}
Q_{P(g) w} \quad \text { is the weighted estimate of peak flow for any } \\
\\
\text { P-percent annual exceedance probability } \\
\text { for a gaged station, in cubic feet per } \\
\text { second; } \\
V_{p, P(g) r} \quad \text { is the variance of estimate at the gaged station } \\
\text { derived from the applicable regional } \\
\text { regression equations for the selected } \\
\text { P-percent annual exceedance probability, } \\
\text { in log units; } \\
\text { is the estimate of peak flow at the gaged } \\
\text { station from the log-Pearson Type III } \\
\text { analysis for the selected P-percent annual } \\
\text { exceedance probability, in cubic feet per } \\
\text { second; } \\
\text { is the variance of estimate at the gaged station } \\
\text { from the log-Pearson Type III analysis for } \\
\text { the selected P-percent annual exceedance } \\
\text { probability, in log units; and } \\
\text { is the peak-flow estimate for the P-percent } \\
\text { annual exceedance probability at the } \\
\text { gaged station derived from the applicable } \\
\text { regional regression equations, in cubic feet } \\
\text { per second. }
\end{array}
$$

When the variance of estimate corresponding to one of the estimates is high, the uncertainty also is high, and so the weight for that estimate is relatively small. Conversely, when the variance of estimate is low, the uncertainty also is low and so the weight is correspondingly large. The variance of estimate associated with the weighted estimate, $V_{p, P(g) w}$, is computed using the following equation:

$$
V_{p, P(g) w}=\frac{V_{p, P(g) s} V_{p, P(g) r}}{V_{p, P(g) s}+V_{p, P(g) r}}
$$

The variance of estimated values associated with the weighted estimates is shown in table 6 . Using variances provides an accurate characterization of the underlying uncertainty of the various flow estimates.

\section{Model Verification and Diagnostics}

The set of equations listed in table 4 are applicable for ungaged, unregulated streams in an urban drainage basin. These equations are statistical models that should be interpreted and applied within the limits of the independent variables. The results are best-fit estimates with an associated scatter or variance.

One of the performance metrics used to measure the WLS regression analyses in WREG is the pseudo coefficient of determination $R_{\text {pseudo }}^{2}$. For OLS regression analyses, the coefficient of determination, $R^{2}$, is used to measure the proportion of the variation in the dependent variable explained by the independent variables. In contrast, the statistic, $R^{2}$ for WLS analyses only considers the amount of variability in the dependent variable explained by the model, removing the effect of the time-sampling error. The highest $R_{p s e u d o}^{2}$ was 96.7 percent for the 4 percent annual exceedance probability (table 7). The lowest $R_{\text {pseudo }}^{2}$ was 92.8 percent for the 0.2 -percent annual exceedance probability. The accuracy of the regression analyses is lower with higher frequency floods. As station frequency curves are extrapolated out to the 0.2-percent annual exceedance probability, the uncertainty increases because of the short period of record at streamgages. Continuing to collect record at existing streamgages or documenting historical floods to extend record lengths at streamgages for EMA analyses may reduce the uncertainty in estimating rare floods.

The accuracy of peak-discharge regression equations are described by the standard model error and standard error of prediction (Ries and Dillow, 2006). The standard model error is a measure of how well the estimated peak discharges generated using an equation agree with the peak-flow statistics generated from streamgage records that were used to create the equation. The standard error of prediction is derived from the sum of the model error and the sampling error, and is a measure of how accurately the estimated peak discharges generated using an equation will be able to predict the true value of peak discharge for the selected recurrence interval. Approximately two thirds of the estimates obtained from the equations for ungaged sites will have errors less than than the noted standard errors of prediction. The standard model error ranged from $0.008 \log$ units (-18.6 to 22.9 percent) for the 10-, 4-, and 2-percent annual exceedance probabilities to $0.019 \mathrm{log}$ units (-27.2 to 37.4 percent) for the 0.2-percent annual exceedance probabilities. The average standard model error of prediction was slightly higher with a range of $0.009 \log$ units (-19.6 to 24.4 percent) for the 10 - and 4-percent annual exceedance probability to $0.022 \log$ units (-28.9 to 40.7 percent) for the 0.2 -percent annual exceedance probability (table 7).

A prediction interval is a useful indicator of the uncertainty in the use of the regression equations and can be calculated for a specific streamgage (Ries and Dillow, 2006). A minimum and maximum value is computed with a stated probability that the true value of the estimated discharge is within the interval. A 90-percent prediction interval for the 1-percent 


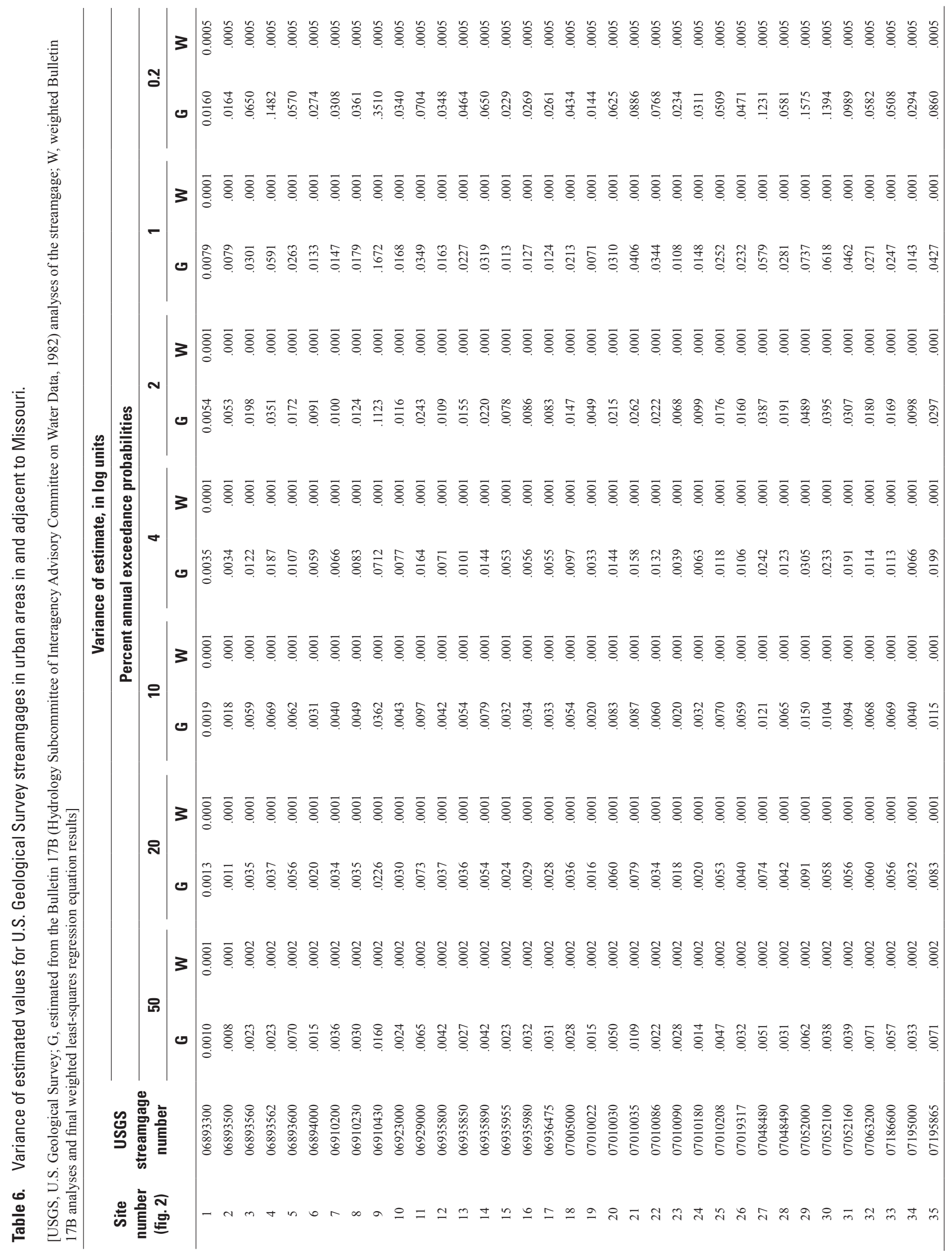


Table 7. Accuracy statistics of weighted least-squares regression equations for urban basins in Missouri.

$\left[\mathrm{R}^{2}\right.$, coefficient of determination]

\begin{tabular}{ccccccc}
\hline $\begin{array}{c}\text { Percent annual } \\
\text { exceedance prob- } \\
\text { ability }\end{array}$ & $\begin{array}{c}\text { Pseudo } \mathbf{R}^{2} \\
\text { (percent) }\end{array}$ & \multicolumn{2}{c}{ Standard model error } & & \multicolumn{2}{c}{ Average standard error of prediction } \\
\cline { 7 - 7 } \cline { 6 - 7 } & & Logarithm units & Percent & & Logarithm units & Percent \\
\hline 50 & 95.3 & 0.012 & -22.3 to 28.7 & & 0.013 & -23.1 to 30.0 \\
20 & 96.1 & .009 & -19.6 to 24.4 & & .010 & -20.6 to 25.9 \\
10 & 96.6 & .008 & -18.6 to 22.9 & & .009 & -19.6 to 24.4 \\
4 & 96.7 & .008 & -18.6 to 22.9 & & .009 & -19.6 to 24.4 \\
2 & 96.4 & .008 & -18.6 to 22.9 & & .010 & -20.6 to 25.9 \\
1 & 95.8 & .010 & -20.6 to 25.9 & & .012 & -22.3 to 28.7 \\
.2 & 92.8 & .019 & -27.2 to 37.4 & & .022 & -28.9 to 40.7 \\
\hline
\end{tabular}

Table 8. Model error variances, Student's t distribution, and covariance matrices of regression equations for urban basins in Missouri.

[ $t$, the critical value from the Student's $t$ distribution for the 90-percent prediction interval]

\begin{tabular}{|c|c|c|c|c|c|c|}
\hline \multirow{2}{*}{$\begin{array}{c}\text { Percent annual } \\
\text { exceedance } \\
\text { probability }\end{array}$} & \multirow{2}{*}{$\begin{array}{c}\text { Model error } \\
\text { variance, } \\
\sigma^{2}\end{array}$} & \multirow[b]{2}{*}{$t$} & \multicolumn{4}{|c|}{ Covariance matrix } \\
\hline & & & & Intercept & $\begin{array}{c}\text { Drainage area } \\
\text { (DRNAREA) }\end{array}$ & $\begin{array}{l}\text { Impervious area } \\
\text { (IMPNLCD01) }\end{array}$ \\
\hline \multirow[t]{3}{*}{50} & 0.0122 & 1.694 & Intercept & 0.002985 & -0.000672 & -0.000073 \\
\hline & & & Drainage Area & -.000672 & .000741 & -.000001 \\
\hline & & & Impervious area & -.000073 & -.000001 & .000003 \\
\hline \multirow[t]{3}{*}{20} & .0094 & 1.694 & Intercept & .002701 & -.000617 & -.000066 \\
\hline & & & Drainage Area & -.000617 & .000654 & .000000 \\
\hline & & & Impervious area & -.000066 & .000000 & .000002 \\
\hline \multirow[t]{3}{*}{10} & .0080 & 1.694 & Intercept & .002754 & -.000639 & -.000067 \\
\hline & & & Drainage Area & -.000639 & .000650 & .000000 \\
\hline & & & Impervious area & -.000067 & .000000 & .000003 \\
\hline \multirow[t]{3}{*}{4} & .0076 & 1.694 & Intercept & .003139 & -.000738 & -.000076 \\
\hline & & & Drainage Area & -.000738 & .000722 & .000001 \\
\hline & & & Impervious area & -.000076 & .000001 & .000003 \\
\hline \multirow[t]{3}{*}{2} & .0084 & 1.694 & Intercept & .003679 & -.000869 & -.000089 \\
\hline & & & Drainage Area & -.000869 & .000840 & .000001 \\
\hline & & & Impervious area & -.000089 & .000001 & .000004 \\
\hline \multirow[t]{3}{*}{1} & .0103 & 1.694 & Intercept & .004443 & -.001049 & -.000108 \\
\hline & & & Drainage Area & -.001049 & .001015 & .000001 \\
\hline & & & Impervious area & -.000108 & .000001 & .000004 \\
\hline \multirow[t]{3}{*}{.2} & .0186 & 1.694 & Intercept & .007091 & -.001659 & -.000172 \\
\hline & & & Drainage Area & -.001659 & .001648 & .000001 \\
\hline & & & Impervious area & -.000172 & .000001 & .000007 \\
\hline
\end{tabular}


annual exceedance probability peak discharge should be interpreted to mean that there is 90 -percent confidence that the true value of the estimated peak discharge is within the prediction interval. The parameters needed to compute the minimum and maximum values of the prediction interval are the model error variance, Student's t distribution, and the covariance matrix. These parameters for each flood annual exceedance probability are presented in table 8 .

The urban equations presented in this report will be included in the USGS National Streamflow Statistics (NSS) program. The NSS program is a compilation of all current USGS regional regression equations for estimating streamflow statistics at ungaged sites in a user-friendly interface that operates on computers with Microsoft Windows operating systems. Output from NSS provides indicators of the accuracy of the estimated streamflow statistics, such as the 90-percent prediction interval. A frequency plot also can be generated with the program. The NSS software and accompanying database, and the documentation for the regression equations included in NSS, are available at http://water.usgs.gov/software/. The independent variables, drainage area and impervious area, are denoted as DRNAREA and IMPNLCD01 in the NSS software.

The accuracy and prediction intervals for the equations in table 6 are valid for the range of basin characteristics used to develop the equations. For this study, the drainage area independent variable ranged from 0.28 to 189 square miles (table 9). In contrast, the range in drainage area was 0.28 to 38.9 square miles for the previous statewide urban flood frequency study by Becker (1986). Impervious area is the other independent variable common to both studies. The range of impervious area for this study was 2.3 to 46.0 percent compared to 1 to 34 percent in Becker's (1986) study. A plot indicating the spatial relation of drainage area and percent impervious area for the basins upstream from the 35 USGS streamgages used in this report is shown in figure 5.

The sensitivity of the equations to errors in the independent variables (drainage area and impervious area) was evaluated by changing each independent variable by 10 percent

Table 9. Ranges of basin characteristics used to develop the regression equations for urban basins in Missouri.

\begin{tabular}{cccc}
\hline \multirow{2}{*}{$\begin{array}{c}\text { Basin } \\
\text { characteristic }\end{array}$} & \multicolumn{2}{c}{ Basin characteristic statistics } \\
\cline { 2 - 4 } & Minimum & Mean & Maximum \\
\hline $\begin{array}{c}\text { Drainage area } \\
\text { (DRNAREA, } \\
\text { in square miles) }\end{array}$ & 0.28 & 28.8 & 189 \\
$\begin{array}{c}\text { Impervious area } \\
\text { (IMPNLCD01, } \\
\text { in percent) }\end{array}$ & 2.3 & & \\
\hline
\end{tabular}

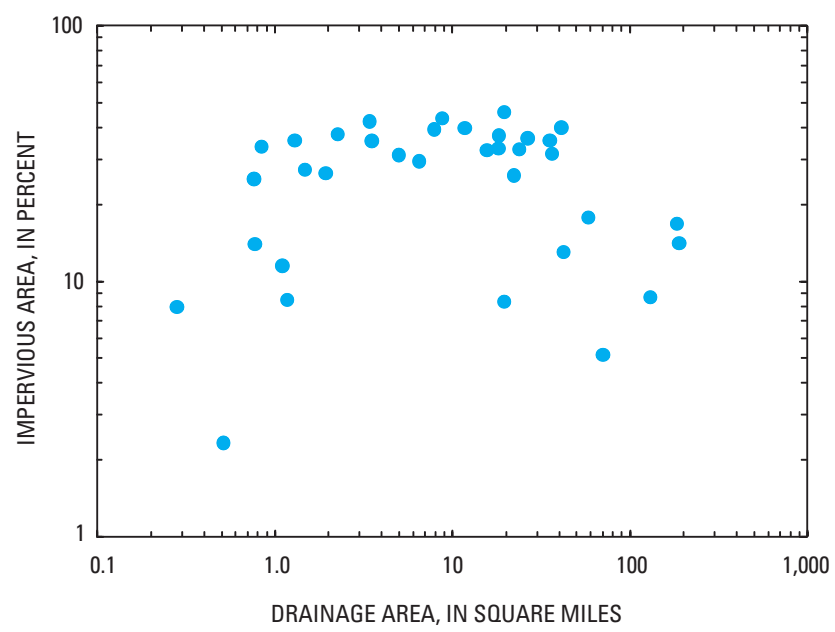

Figure 5. Drainage area and impervious area basin characteristics at U.S. Geological Survey streamgages in urban areas in and adjacent to Missouri.

increments from +20 to -20 percent, while holding the other variable constant. The annual exceedance probabilities of 50-, 20-, 10-, 4-, 2-, 1-, and 0.2-percent were used in the sensitivity analyses and the base computations were the mean values for each independent variable. For the +20 to -20 percent changes in drainage area, the percent change in peak flows ranged from +12.0 to -13.0 percent, respectively (table 10 ). For the +20 to -20 percent changes in impervious area, the percent change in peak flows ranged from +18.6 to -15.7 percent, respectively. The percent change in peak flows was fairly constant for each change in drainage area throughout the range in annual exceedance probabilities; however, for impervious area, the percent change in peak flows for each change in impervious area decreased when going from the 50-percent annual exceedance probability to the 0.2 -percent annual exceedance probability. The sensitivity analyses indicates that as the magnitude of the flood event increases, the effect of the impervious area decreases as the soils become saturated and retain less precipitation, resulting in more runoff per unit area.

A comparison of results from selected regression equations and the maximum recorded flood discharge at each streamgage was done to visualize the magnitude of floods experienced at the streamgages. A plot of the drainage area basin characteristic and maximum recorded flood discharge from table 4 is shown in figure 6 . Two lines shown on the plot represent the results of the 1- and 0.2-percent annual exceedance probabilities derived from the regression equations using an impervious area of 46 percent, the maximum percent impervious area used to develop the equations. Two streamgages in the Brush Creek Basin in Kansas City, Missouri, (sites 3 and 4) recorded floods greater than a 0.2 -percent annual exceedance probability estimate from the regression equations. The maximum flood at site 3 occurred on September 12, 1977, and the maximum flood at site 4 occurred on October 4, 1998 (site 4 was not in operation in 1977). At site 26, the flood of September 14, 2008, was greater than the 
Table 10. Results of sensitivity analyses presented as percent change in computed flood discharge as a result of a 10and 20-percent change of the input basin characteristic.

\begin{tabular}{crrrrrrr}
\hline $\begin{array}{c}\text { Percent change } \\
\text { in basin } \\
\text { characteristic }\end{array}$ & \multicolumn{7}{c}{$\begin{array}{c}\text { Percent change in computed flood discharge by the regression equation for estimating floods having a } \\
\text { percent annual exceedance probability of }\end{array}$} \\
\cline { 2 - 8 } & $\mathbf{5 0}$ & $\mathbf{2 0}$ & $\mathbf{1 0}$ & $\mathbf{4}$ & $\mathbf{2}$ & $\mathbf{1}$ & $\mathbf{0 . 2}$ \\
\hline \multicolumn{7}{c}{} & \multicolumn{7}{c}{ Drainage area (DRNAREA) } \\
\hline+20 & 11.6 & 11.5 & 11.5 & 11.6 & 11.7 & 11.8 & 12.0 \\
+10 & 5.9 & 5.8 & 5.9 & 5.9 & 6.0 & 6.0 & 6.1 \\
-10 & -1.9 & -1.9 & -1.9 & -1.9 & -1.9 & -1.9 & -1.9 \\
-20 & -12.6 & -12.5 & -12.5 & -12.6 & -12.7 & -12.8 & -13.0 \\
\hline & & \multicolumn{7}{c}{ Impervious area (IMPNLCD01) } \\
\hline+20 & 18.6 & 14.4 & 13.0 & 11.3 & 10.3 & 8.9 & 7.6 \\
+10 & 9.1 & 7.1 & 6.4 & 5.1 & 5.1 & 4.4 & 3.8 \\
-10 & -8.3 & -6.6 & -6.0 & -4.9 & -4.9 & -4.3 & -3.7 \\
-20 & -15.7 & -12.6 & -11.5 & -9.3 & -9.3 & -8.2 & -7.1 \\
\hline
\end{tabular}

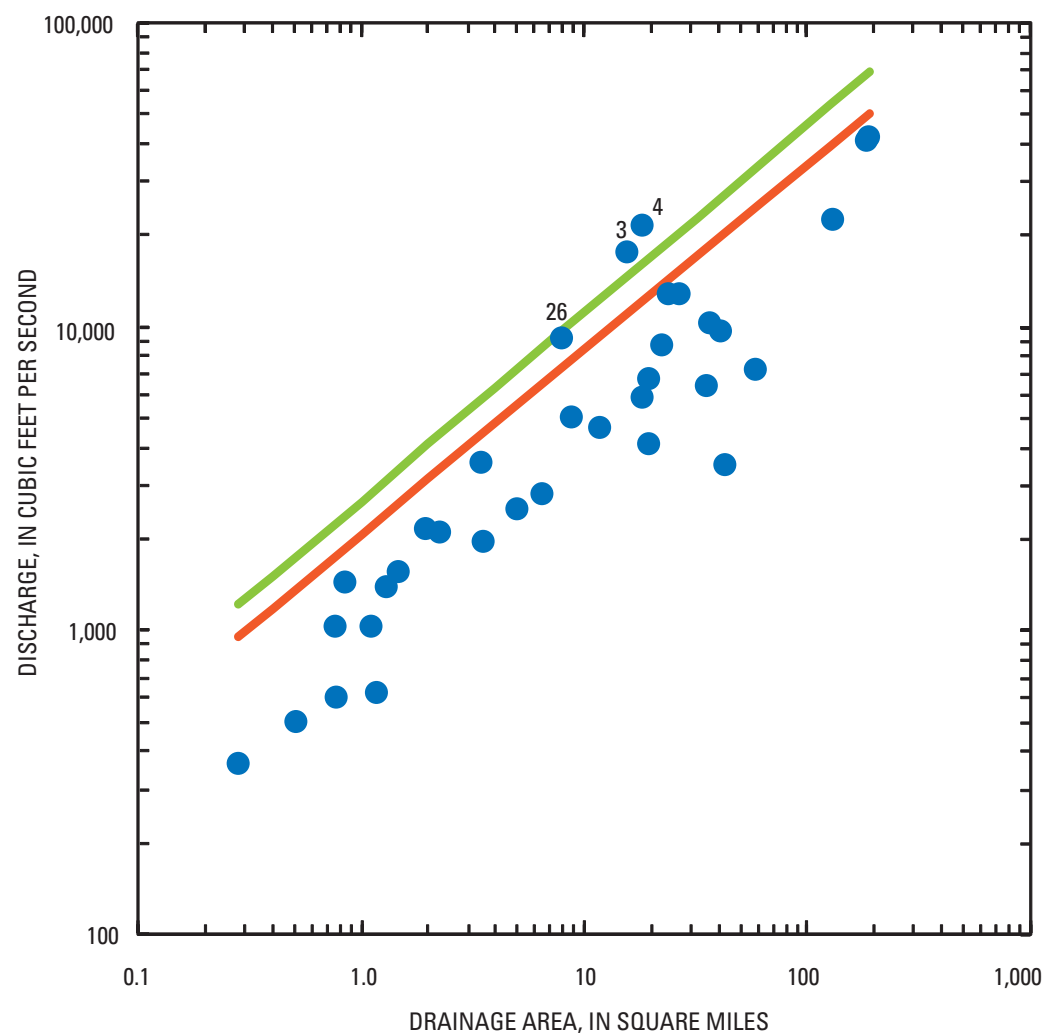

EXPLANATION

Estimated peak flows for the 1-percent annual exceedance probability flood using 46 percent impervious area

Estimated peak flows for the 0.2-percent annual exceedance probability flood using 46 percent impervious area

4 Maximum recorded flood discharge greater than the 1-percent annual exceedance probability flood at U.S. Geological Survey streamgages (site number, table 4)

Figure 6. Maximum recorded flood discharges at U.S. Geological Survey streamgages in urban areas in and adjacent to Missouri in relation to estimated peak flows from the regression equations for the 1- and 0.2-percent annual exceedance probability flood using 46 percent impervious area. 
1-percent annual exceedance probability flood estimate from the regression equations.

The results of this study were compared to computed flows for the current rural (Alexander and Wilson, 1995) and existing urban (Becker, 1986) regression equations at seven selected streamgages for the 1-percent annual exceedance probability. The seven streamgages selected represent a variety of combinations of drainage area values and impervious area values used in this study. It should be noted that the rural equations are not intended to be used on urbanized basins and the range of basin characteristics for the urban equations in this study were outside of the range of basin characteristics that Becker (1986) used to develop his equations. The comparison was done to examine differences in the equations. The range in percent differences between the urban equation in this study and the rural equation presented in Alexander and Wilson was 3 to 52 percent (table 11). Comparing the percent differences from this study to the previous urban study (Becker, 1986), with drainage area and percent impervious area as basin characteristics from Becker (1986), the range in percent differences was -255 to 10 percent. The largest differences shown in table 11 are at streamgages with drainage areas (70.3 and 189 square miles) much larger than the maximum used to develop Becker's 1986 equation (38.9 square miles), and direct comparisons may not be valid for these streamgages. Site 32 was the only streamgage with a positive difference, implying that for extremely small drainage areas Becker's equation may result in slightly lower peak flow values. The overall comparison between the urban equations indicates a reduction in estimated peak flows for urban basins.

\section{Summary}

The report presents the results of regression analyses on streamgage frequencies using 35 U.S. Geological Survey streamgages located in urban basins in and adjacent to Missouri. It describes the need and purpose of the study, data development for the study, and regionalization of the regression equations. Model verification, diagnostics, and limits also are presented. This report supersedes previous urban flood frequency investigations in Missouri.

The best available information is needed in the proper design of bridges and culverts, land-use planning, and flood risk assessments. Basin characteristics affect the hydraulic design of infrastructure along streams. Urbanized basins typically result in higher peak flows and decreased dependent times compared to rural basins. The last set of urban equations for the state of Missouri was developed in 1986 using data through the 1984 water year. Since 1984, 24 years of additional streamflow data have been collected, and 15 streamgages have been established or re-activated in urban basins enhancing the base data set used in regression analyses. Improvements in the characterization of basins exist today by implementation of high resolution digital datasets. Statistical analyses are more rigorous than in the mid-1980s with the use of expected moments algorithms and weighted least-squares regression techniques. Use of the additional data and improved statistical techniques will provide more accurate estimates of peak flow at gaged and ungaged sites in urban basins; therefore, the U.S. Geological Survey conducted a study, in cooperation with the Metropolitan St. Louis Sewer District, to develop and apply a new set of regression equations for

Table 11. Flood discharges at the 1-percent annual exceedance probabilities for rural and urban regression equations at selected U.S. Geological Survey streamgages.

$\left[\mathrm{ft}^{3} / \mathrm{s}\right.$, cubic feet per second; USGS, U.S. Geological Survey; $\mathrm{mi}^{2}$, square miles; $\mathrm{ft} / \mathrm{mi}$; feet per mile]

\begin{tabular}{|c|c|c|c|c|c|c|c|c|c|}
\hline \multirow[b]{2}{*}{$\begin{array}{l}\text { Site } \\
\text { number } \\
\text { (fig. 2) }\end{array}$} & \multirow[b]{2}{*}{$\begin{array}{l}\text { USGS } \\
\text { station } \\
\text { number }\end{array}$} & \multirow[b]{2}{*}{$\begin{array}{c}\text { Drainage } \\
\text { area } \\
\left(\mathrm{mi}^{2}\right)\end{array}$} & \multirow[b]{2}{*}{$\begin{array}{l}\text { Impervious } \\
\text { area } \\
\text { (percent) }\end{array}$} & \multirow[b]{2}{*}{$\begin{array}{l}\text { Main-channel } \\
\text { slope } \\
\text { (ft/mi) }\end{array}$} & \multicolumn{3}{|c|}{ Flood discharge $\left(\mathrm{ft}^{3} / \mathrm{s}\right)$} & \multicolumn{2}{|c|}{$\begin{array}{l}\text { Difference in rural } \\
\text { and urban regression } \\
\text { equations, in percent }\end{array}$} \\
\hline & & & & & $\begin{array}{c}\text { Rural } \\
\text { regression } \\
\text { results } \\
\text { (Alexander } \\
\text { and Wilson, } \\
1995 \text { ) }\end{array}$ & $\begin{array}{c}\text { Urban } \\
\text { regression } \\
\text { results } \\
\text { (Becker, } \\
\text { 1986) }\end{array}$ & $\begin{array}{l}\text { Urban } \\
\text { regression } \\
\text { results } \\
\text { (this study) }\end{array}$ & Rural & Urban \\
\hline 6 & 06894000 & 189 & 14.1 & 7.4 & 22,900 & 107,000 & 30,100 & 24 & -255 \\
\hline 8 & 06910230 & 70.3 & 5.15 & 11.2 & 13,900 & 41,000 & 14,300 & 3 & -187 \\
\hline 17 & 06936475 & 41.0 & 40 & 8.0 & 8,690 & 35,400 & 18,000 & 52 & -97 \\
\hline 19 & 07010022 & 8.74 & 43.5 & 29 & 4,950 & 10,100 & 7,470 & 34 & -35 \\
\hline 21 & 07010035 & 1.47 & 27.3 & 50.2 & 1,870 & 2,180 & 1,940 & 4 & -12 \\
\hline 29 & 07052000 & 19.5 & 46 & 22.6 & 7,810 & 19,600 & 12,700 & 39 & -54 \\
\hline 32 & 07063200 & .28 & 7.94 & 85.4 & 503 & 467 & 519 & 3 & 10 \\
\hline
\end{tabular}


estimating the magnitude and frequency of floods in urban basins in Missouri.

Streamgages in urban areas throughout and adjacent to Missouri were evaluated for use in this study. Criteria in the selection of streamgages included period of record, minimal changes in urbanization during the record period, minimal diversions and storage in the basin, and well-defined streamgage ratings. The initial list of streamgages contained more than 70 streamgages. After application of the criteria, the final number of streamgages for use in this study was 35 . Of the 35 streamgages, 30 were within Missouri and 5 were outside of the state.

Flood-frequency estimates for each streamgage were computed from the annual series of peak-flow data retrieved from the U.S. Geological Survey National Water Information System. The analyses were done according to methods recommended in Bulletin 17B by the Interagency Advisory Committee on Water Data. The flood-frequency estimates are expressed in terms of exceedance probabilities, which are the reciprocals of the recurrence intervals. A log-Pearson Type III frequency distribution was fitted to the logarithms of the annual peak flows. The program PEAKFQ was used to compute the flood-frequency statistics. Within the PEAKFQ program is the Expected Moments Algorithm that employs the method of moments technique, which is compatible with Bulletin 17B. The algorithm uses an iterated least-squares method for fitting regression models to censored data.

Ordinary least-squares was used to determine the best set of independent variables for the regression equations. Three general criteria were used to select potential basin characteristics for use in the ordinary least-squares regression analyses. The first criterion was a basin characteristic's theoretical relation to flood flows. The second criterion was the use of basin characteristics in previous studies. The third and final criterion was the ability to measure the basin characteristics using digital datasets and GIS technology. The results of the selection process resulted in four basin characteristics for evaluation using ordinary least-squares regression: (1) drainage area, (2) main channel slope, (3) mean basin slope, and (4) percent impervious area.

The selection and location of the streamgages for this study limited the definition of separate hydrologic regions in the state. To test for potential geographic bias, the residuals from the ordinary least-square regression analyses were plotted on a state map. Overall, no geographic bias was present in the results that would require creating multiple regions. An examination of the residuals compared to drainage area and percent impervious area indicates that the model is satisfactorily meeting the assumptions of multiple-linear-regression techniques. Examination of observed peak flows and the estimated peak flows indicated no climatic or temporal bias existed in the data.

The ordinary least-squares results were evaluated on the basis of Mallow's $C p$ statistic, the adjusted coefficient of determination, and the statistical significance of the independent variables. The dependent variable peak flow from streamgage frequency analyses and independent variable drainage area were base-10 logarithmically transformed for use in the regression equations to improve the linear relation in the analyses. The independent variable, percent impervious area, was not transformed as it was used as a percentage and the resulting logarithmic transformation did not improve the linear relation with the dependent variable peak flow.

Drainage area and impervious area were retained in the final regression equations from ordinary least-squares analysis. Drainage area was computed using GIS techniques and a statewide 10-meter grid (higher resolution elevation data from urban areas, when available). Impervious area was computed from National Land Cover Dataset 2001 percentage impervious area data. The impervious area computed for each urban basin was checked against historical imagery and 7.5-minute topographic maps to verify that substantial changes in development did not occur during or outside of the period of record. Of the 35 streamgages, 8 streamgages had National Land Cover Dataset impervious area computations lowered from 1 to 23 percent to reflect the amount of urbanization during the period of streamflow data collection.

The final regression coefficients were computed using weighted least-squares techniques as weighted regression techniques provided better estimates of the accuracy of the equations than ordinary least-squares techniques. Improvements in the weighted equations occurred when streamflow records at streamgages are of different and varying lengths. Weighted least-squares techniques give less weight to streamgages that have shorter periods of record than streamgages with longer periods of records. The results of the weighted least-squares were compiled for the 50-, 20-, 10-, 4-, 2-, 1-, and 0.2-percent annual exceedance probabilities floods for Missouri. The results of this study will be included in the National Streamflow Statistics program by the U.S. Geological Survey at http://water.usgs.gov/software/.

The set of equations presented in this report are applicable for urban areas within Missouri that have drainage areas in the range of 0.28 to 189 square miles and impervious areas in the range of 2.3 to 46.0 percent. The standard model error ranged from 0.008 to $0.019 \mathrm{log}$ units. The standard model error of prediction was slightly higher with a range of 0.009 to $0.022 \log$ units. The sensitivity of the equations to errors in the computation of the independent variables was evaluated. $A+20$ to -20 percent change in drainage area resulted in a percent change in peak flow from +12.0 to -13.0 . For $a+20$ to -20 percent change in impervious area, the percent change in peak flows ranged from +18.6 to -15.7 percent.

A plot of the regression results and maximum recorded flood discharges for each streamgage was created to visualize the magnitude of floods experienced at each streamgage. An impervious area of 46 percent was used in the regression equations for the 1- and 0.2-percent annual exceedance probabilities. The two largest floods occurred in the Brush Creek Basin in 1977 and 1998 at site numbers 3 and 4, respectively. These floods exceeded the 0.2-percent annual exceedance probability based on the regression equations. Another flood in 2008, at 
site number 26, exceeded the 1-percent annual exceedance probability flood based on the regression equation.

Seven streamgages were selected to compare the results of the existing rural flood frequency equations, the existing urban equations, and this study. This comparison was done to qualitatively define the differences in the three sets of equations for the 1-percent annual exceedance probability. The results of this study indicated that the peak flows were 3 to 52 percent higher than estimates from the rural equation. Comparison of this study to the existing urban equations developed in 1986, using the independent variables drainage area and impervious, indicated the peak flows were 255 percent lower to 10 percent higher than estimates from the 1986 study. The overall comparison of the two urban equations indicates a reduction in estimated peak flow values for the 1-percent annual exceedance probability flood using regression equations from this study.

\section{Selected References}

Alexander, T.W., and Wilson, G.L., 1995, Techniques for estimating the 2- to 500-year flood discharges on unregulated streams in rural Missouri: U.S. Geological Survey WaterResources Investigations Report 95-4231, 33 p.

Becker, L.D., 1986, Techniques for estimating flood-peak discharges from urban basins in Missouri: U.S. Geological Survey Water-Resources Investigations Report 86-4322, $38 \mathrm{p}$.

Becker, L.D., and Alexander, T.W., 1983, Floods in Kansas City, Missouri and vicinity, August 12-13, 1982: U.S. Geological Survey Water-Resources Investigations Report 83-4141, 35 p.

Cohn, T., Lane, W.M., and Baier, W.G., 1997, An algorithm for computing moments-based flood quantile estimates when historical flood information is available: Water Resources Research., v. 33 no. 9, p. 2,089-2,096.

Cohn, T., Lane, W.L., and Stedinger, J.R., 2001, Confidence intervals for Expected Moments Algorithm flood quantile estimates: Water Resources Research, v. 37, no. 6, p. 1,695-1,706.

Cook, R.D., 1977, Detection of influential observation in linear regression: Technometrics, v. 19, p. 15-18.

Eng, Ken, Chen, Yin-Yu, and Kiang, J.E., 2009, User's guide to the weighted-multiple-linear-regression program (WREG version 1.0): U.S. Geological Survey Techniques and Methods, book 4, chap. A8, 21 p. (Also available at http://pubs. usgs.gov/tm/tm4a8.)
Feaster, T.D., Guimaraes, W.B., 2004, Estimating the magnitude and frequency of floods in small urban streams in South Carolina, 2001: U.S. Geological Survey Scientific Investigations Report 2004-5030, 68 p.

Flynn, K.M., Kirby, W.H., and Hummel, P.R., 2006, User's manual for program PeakFQ, Annual Flood Frequency Analysis Using Bulletin 17B Guidelines: U.S. Geological Survey Techniques and Methods book 4, chap. B4, 42 p.

Gotvald, A.J., Feaster, T.D., and Weaver, J.C., 2009, Magnitude and frequency of rural floods in the southeastern United States, 2006-Volume 1, Georgia: U.S. Geological Survey Scientific Investigations Report 2009-5043, 120 p.

Griffis, V.W., Stedinger, J.R., and Cohn, T.A., 2004, Log Pearson type 3 quantile estimators with regional skew information and low outlier adjustments: Water Resources Research, v. 40, W07503.

Griffis, V.W., and Stedinger, J.R., 2007a, The LP3 distribution and its application in flood frequency analysis, II-Parameter estimation methods: Journal of Hydrologic Engineering, v. 12 , no. 5 , p. 492-500.

Griffis, V.W., and Stedinger, J.R., 2007b, The use of GLS regression in regional hydrologic analyses: Journal of Hydrology, v. 344, p. 82-95.

Helsel, D.R., and Hirsch, R.M., 1992, Statistical methods in water resources: New York, Elsevier, p. 326.

Hydrology Subcommittee of Interagency Advisory Committee on Water Data, 1982, Guidelines for determining flood flow frequency (revised): U.S. Geological Survey, Office of Water Data Coordination, Bulletin 17B, 28 p., 14 app., and $1 \mathrm{pl}$.

Missouri Climate Center, 2009, Climate of Missouri, accessed June 2009 at http://climate.missouri.edu/climate.php.

Ries, K.G. III, and Dillow, J.J.A., 2006, Magnitude and frequency of floods on nontidal streams in Delaware: U.S. Geological Survey Scientific Investigations Report 20065146, 57 p.

Sauer, V.B., Thomas, W.O., Jr., Stricker, V.A., and Wilson, K.V., 1983, Flood characteristics of urban watersheds in the United States: U.S. Geological Survey Water-Supply Paper 2207, 63 p.

Spencer, D.W., and Alexander, T.W., 1978, Techniques for estimating the magnitude and frequency of floods in St. Louis County, Missouri: U.S. Geological Survey WaterResources Investigations Report 78-139, 23p.

Stedinger, J.R., and Tasker, G.D., 1985, Regional hydrologic analysis 1 - ordinary, weighted, and generalized least squares compared: Water Resources Research, v. 21, no. 9, p. 1,421-1,432. 
Tasker, G.D., 1980, Hydrologic regression with weighted least-squares: Water Resources Research, v. 16, no. 6, p. $1,107-1,113$.

U.S. Census Bureau, 2001, Census 2000 summary file 1 technical documentation: U.S. Census Bureau, Washington, D.C., U.S.A.

U.S. Geological Survey, 2001, Multi-Resolution Land Characteristics Consortium, accessed June 2009 at $h t t p: / / w w w$. mrlc.gov/mrlc2k_nlcd.asp.

Publishing support provided by:

Rolla Publishing Service Center

For more information concerning this publication, contact:

Director, USGS Missouri Water Science Center

1400 Independence Road

Rolla, M0 65401

(573) 308-3667

Or visit the Missouri Water Science Center Web site at:

http://mo.water.usgs.gov/ 

